The Censor's Rod:

Textual Criticism, Judgment, and Canon Formation in Late Antiquity and the Early Middle Ages*

IRENE VAN RENSWOUDE

This is a preprint version (starting on the next page) of an article that will appear in M. Teeuwen and I. van Renswoude (ed.), The Annotated Book in the Early Middle Ages. Practices of Reading and Writing, Turnhout: Brepols 2018 (Utrecht Studies in Medieval Literacy 38), p. 555-595. 


\title{
The Censor's Rod:
}

\section{Textual Criticism, Judgment, and Canon Formation in Late Antiquity and the Early Middle Ages*}

\author{
IRENE VAN RENSWOUDE
}

$\mathrm{T}$

his is a dagger: $\dagger$ When we encounter this typographic sign, it usually spells bad news. The symbol indicates death, extinction, limitation, exclusion, or destruction. Whereas its cheerful companion, the star-shaped asterisk, signifies bright new beginnings, the dagger marks their end (David Bowie * $1947 \uparrow 2016) .{ }^{1}$ Editors use the dagger to identify transcription errors and text corruption. The sign (which is sometimes interpreted as a cross) occasionally serves less dramatic functions, such as linking a footnote to a printed text, but only when the bright asterisk has already been used. ${ }^{2}$ The typographic

I would like to thank Janneke Raaijmakers, Mariken Teeuwen, and Evina Steinová for their valuable comments to earlier versions of this article. The research for this article was part of the VIDI project 'Marginal Scholarship', and the Open Competition project 'The Art of Reasoning', both funded by the Netherlands Organisation of Scientific Research (NWO). The translations in this article are mine, unless indicated otherwise.

1 J. HoEFLER, "House of the flying reference marks, or Quillon \& Choil (4 June, 2009)", at: http://www.typography.com/blog/house-of-flying-reference-marks (accessed 14 Nov 2016).

2 K. Houston, Shady Characters: The Secret Life of Punctuation, Symbols and Other

The Annotated Book in the Early Middle Ages: Practices of Reading and Writing, ed. M.J. TEEUWEN and I. VAN Renswoude, Utrecht Studies in Medieval Literacy, 38 (Turnhout: Brepols, 2017), pp. 555-595. 
dagger has a long and fascinating history. It developed out of an ancient symbol known as the obelus that was used for text correction, which got its name from the Greek word obelos meaning 'roasting spit' and its diminutive form obeliskos: sharp end of a lance. In Latin the symbol was called a virgula, 'little twig or rod', from virga, 'flogging rod'. The symbol could be rendered as a plain line - or dotted line $\div$ or occasionally a dotted slash forward $\%$. Although the graphic shape of the ancient obelus was more abstract and neutral-looking than the evocative image of the modern typographic dagger, this 'roasting spit' visually represented the act of cutting, piercing and destroying, just like our dagger.

In this article I explore how between 200 and 900 the function of the graphic symbol of the obelus changed from being an instrument of textual criticism to a tool of censure, from controlling the form of texts to controlling their content. In Antiquity, the sign of the obelus was used to mark corrupted or doubtful passages and served the scholarly enterprise of textual criticism. In the early Middle Ages, the sign was used to assess manuscripts with heretical, pagan, suspicious, or otherwise offensive content. Other critical signs could be used for the same purpose, such as the theta, but the obelus was the most popular among the signs expressing negative judgment and rejection. ${ }^{3}$ Although the obelus and other critical signs retained their function in the enterprise of textual criticism throughout the period under scrutiny (and long after), they developed alongside a new role in the transmission and reception of heterodox texts, as we will see.

The first question I want to address here is when (and why) this shift in function took place. To find an answer I will not only explore the practice of adding obeli in the margins of heterodox texts, but will also take a close look at the imagery used in descriptions of the symbol. What were the nouns and verbs that described the agency of the critical sign, and did that agency concur with the practice that we see in the margins of manuscripts of the period? The second question is, whether the obelus can reasonably be called a 'sign of censorship', or whether the notion of censorship is unfit to describe processes of regulation in the manuscript culture of late Antiquity and the early Middle

Typographical Marks (New York, London 2013), p. 97.

3 I. VAN RENSWOUDE and E. STEINOVÁ, "The annotated Gottschalk: Critical signs and control of heterodoxy in the Carolingian age", in: La controverse carolingienne sur la prédestination. Histoire, textes, manuscrits, ed. P. Chambert-Protat, J. Delmulle, W. Pezé and J. C. Thompson, (Turnhout: Haut Moyen Âge 32), pp. 243-270. 
Ages. ${ }^{4}$ According to the traditional definition of censorship, the act of censoring implies blocking something from being read, heard, or seen. ${ }^{5}$ In the following I will discuss manuscripts and texts from the third to the ninth century, but the main focus of this article will lie on developments in the late fourth century. For it was in the 390s, during a quarrel between Jerome of Stridon and Rufinus of Aquileia over the translation and transmission of unorthodox texts, that the development of the obelus into an instrument of control and judgment took a decisive turn. I will start this investigation, however, in the early Middle Ages, and with this period I will also end.

\section{The Obelus in Medieval Sign Lists and Manuscript Practice}

Several lists of editorial symbols circulated in the Middle Ages, as a recent inventory of Evina Steinová has shown. ${ }^{6}$ One of the oldest medieval sign lists stemmed from Isidore, Bishop of Seville (c. 560-c. 636), who assembled knowledge from classical sources into one compendium, the Etymologiae. In the first book, dealing with grammar, Isidore included a list of twenty-six signs which he called 'signs of judgment' (notae sententiarum), which the ancients had employed, he said, to annotate literature, notably poetry and history, of the

4 This article owes much to discussions with my colleague Evina Steinová and to our joint quest between 2012 and 2015 to find examples of the obelus in early medieval manuscripts. For Evina, this investigation was part of her research into technical signs (see the reference to her dissertation below); for me it fitted an ongoing interest in mechanisms of knowledge regulation. The question as to whether the obelus can reasonably be called a 'sign of censorship' has been a frequent topic of our discussions. I thank Evina for the past years of fruitful cooperation and spirited discussion. I would also like to thank David Ganz: it was his discussion of the evidence of annotation and 'notes of disapprobation', which sparked this 'quest for the obelus'. D. GANZ, Corbie in the Carolingian Renaissance (Sigmaringen, 1990: Beihefte der Francia 20), pp. 68101, esp. p. 69.

5 See for example J.C. LAURSEN, “Censorship", in: The New Dictionary of the History of Ideas, ed. M.C. HoROwITZ (Detroit, 2005), pp. 290-295; The Oxford Dictionary for Journalism, ed. T. HARCuP (Oxford, 2014). For a more flexible, less traditional understanding of mechanisms of censorship, see: S.C. JANSEN, Censorship: The Knot that Binds Power and Knowledge (Oxford, 1999); F. SCHAUER, “The ontology of censorship", in: Censorship and Silencing: Practices of Cultural Regulation, ed. R.C. Post (Los Angeles, 1998), pp. 147-168.

6 E. SteINOVÁ, Notam superponere studui: The Use of Technical Signs in the Early Middle Ages (unpublished dissertation, Utrecht University, 2016), Appendix 3: "Sign treatises produced from the $1^{\text {st }}$ to the $15^{\text {th }}$ century", pp. 316-352. 
most famous authors of Antiquity. ${ }^{7}$ Isidore described the sign of the obelus in the following terms:

The obelus, that is a horizontal stroke, is placed next to words or sentences that are needlessly repeated, or next to those places where the reading notes some untruthfulness, so that like an arrow it may slay the superfluous and pierce the false. For the arrow is called obelos in Greek. ${ }^{8}$

From Isidore's definition we learn that already by the early seventh century the field of the obelus had expanded from the form to the content of a text. According to Isidore, the sign could be used to mark redundancies (form), as well as untruths (content). Yet what exactly the critical sign is meant to 'do' with these falsities and redundancies remains unclear. Isidore used a powerful image to describe the obelus's agency, a piercing arrow, and employed aggressive verbs such as confodere ('stab through') and jugulare ('kill by slitting the throat'), but is not explicit as to what that act of stabbing or killing should entail. Should superfluous or false content be removed, either by scratching it from the surface of the parchment or by leaving it out in the copying process, or is the symbol a sign that shows that the reader / annotator does not approve of certain parts of the text? In other words, is the obelus a tool of censorship or an instrument of interpretation? Isidore's definition of the obelus leaves room for both interpretations.

In early medieval manuscripts we encounter the sign of the obelus usually in the latter function, as an expression of disapproval or rejection. It should be noted here, however, that not every plain line - or dotted line $\div$ that we come across in the margins of medieval manuscripts is necessarily an obelus; the same graphic symbol could be employed as a quotation mark. ${ }^{9}$ Let me give a few examples of manuscripts where the sign unmistakably occurs as a mark of

Isidore of Seville, Etymologiae I, 21, 1, ed. Isidori Hispalensis episcopi Etymologiarum sive originum libri XX, ed. W.M. LINDSAY, (Oxford, 1911), p. 61: "De notis sententiarum. Praeterea quaedam scripturarum notae apud celeberrimos auctores fuerunt, quasque antiqui ad distinctionem scripturarum carminibus et historiis adposuerunt". Steinová showed that many of the 'classical' editorial signs recorded in medieval sign lists were in fact creatively adapted to suit new purposes. STEINOVÁ, Notam superponere studui. I take the translation 'signs of judgment' from Steinová; usually notae sententiarum is translated as 'critical signs'.

8 Isidore of Seville, Etymologiae, I, 21, 2-3, ed. LINDSAY, Etymologiarum libri, p. 61: "Obolus, id est, virgula iacens, adponitur in verbis vel sententiis superflue iteratis, sive in his locis, ubi lectio aliqua falsitate notata est, ut quasi sagitta iugulet supervacua atque falsa confodiat. Sagitta enim Graece ỏ $\beta \varepsilon \lambda o \varsigma$ dicitur".

9 See SteInOVÁ, Notam superponere studui, pp. 392, 393. 


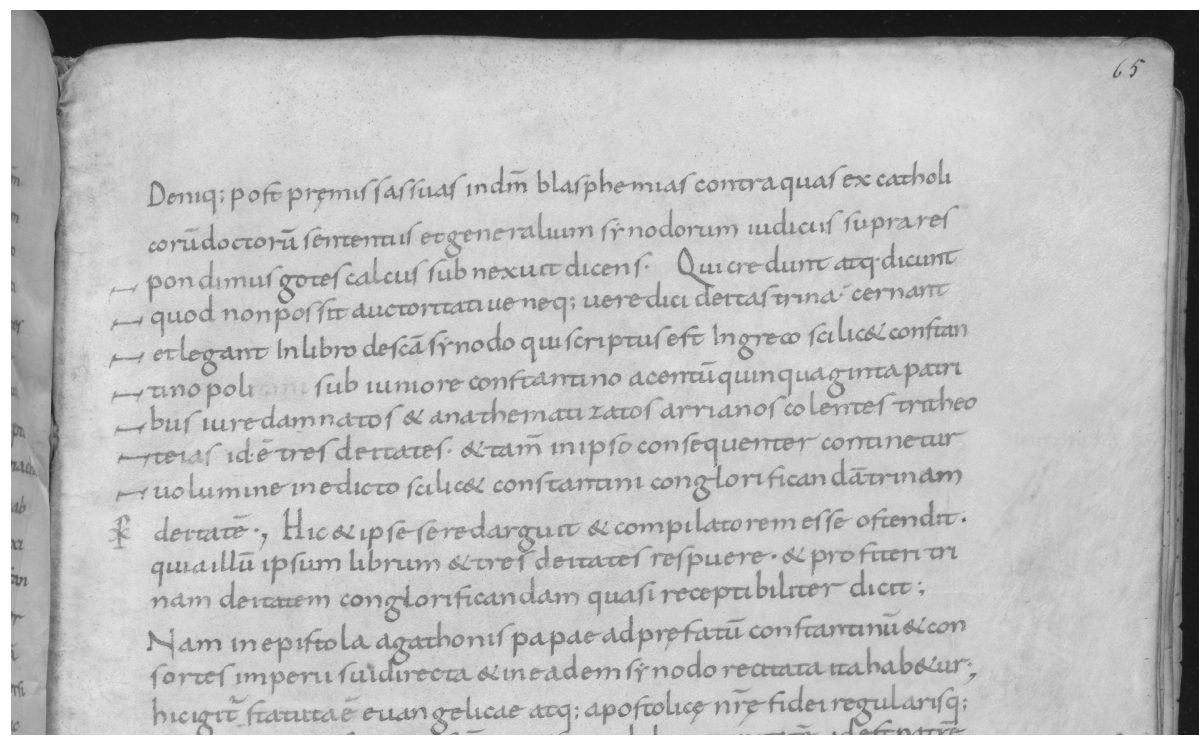

Fig. 1 MS Brussels, Koninklijke Bibliotheek, 1831-33, f. 65r.

disapproval and rejection. In a late eighth- or early ninth-century manuscript of Jerome's Contra Iovinianum (393 CE), an annotator marked the words of the heretic Jovinian with obeli. ${ }^{10}$ In a ninth-century manuscript of Prosper of Aquitaine's De gratia dei et libero arbitrio $(432 \mathrm{CE})$ the statements taken from the work of Prosper's adversary John Cassian were provided with obeli in the margin. ${ }^{11}$ In a late ninth-century manuscript of Hincmar of Reims's De una et non trina deitate (c. 855/857 CE) passages of Hincmar's challenger Gottschalk were obelised, in accordance with the instructions of the author himself (Fig. 1). ${ }^{12}$ As Archbishop Hincmar (c. 806-882) explained in the prologue to his

${ }^{10}$ MS Bamberg, Staatliche Bibliothek, Bibl. Patr. 86 (B.V. 13). I thank Evina Steinová for bringing this manuscript to my attention. On $\mathrm{f} .2 \mathrm{v}$ and $3 \mathrm{r}$ the words of Iovinian are marked with obeli. An interlinear gloss marks the beginning of the quotation from Iovinian with "verba iovini$a n i$ " and adds after the end of the quotation, on $\mathrm{f} .3 \mathrm{v}$ : "contra haec verba ieronimus". For the dating and provenance of the manuscript, see E.A. LOWE, CLA 8, No. 1030.

${ }_{11}$ MS Paris, BNF, lat. 12098 (ninth century, Corbie), digitised at: http://gallica.bnf.fr/ark:/ 12148/btv1b9068399m/f95.item. At ff. 90r-112r one can see the passages that were annotated with obeli. Prosper's own statements against his opponent were annotated with tilted obeli, signifying approval. Cf. VAN RENSwOUdE and STEINOVÁ, The annotated Gottschalk.

${ }_{12}$ MS Brussels, Koninklijke Bibliotheek, 1831-1833, ff. 40r-140v. This section of the manuscript dates from the second half of the ninth century. It was copied in Reims under Hincmar's 
book, he marked Gottschalk's heretical statements with an obelus, and his own arguments, taken from the church fathers, with the sign of the chresimon $(*)$, which meant 'this is very orthodox content' ${ }^{13}$ Obviously, the passages from Gottschalk, consigned with the symbol of the obelus, were not meant to be cut away, as they served the polemical intentions of the author. Removing them would undermine the integrity and purpose of the text. Hincmar's arguments would hardly stand out as 'most orthodox' if they were no longer juxtaposed to the obelised, heretical arguments of his opponent, let alone that it would be possible to follow the argumentation of the text if half of it would be deleted. Hincmar quoted Isidore's definition of the obelus when he explained to his readers what the obeli were doing in his text, which is another indication that the signs were meant to stay in:

I will include into this minor work of our humbleness the pamphlets of Gottschalk in their integrity and I will mark the individual statements with an obelus, that is a lying stroke, according to ancient custom, so that it may pierce through his false arguments as an arrow. ${ }^{14}$

In Hincmar's polemical treatise against Gottschalk, but also in the manuscripts of the polemical works of Prosper and Jerome, the obeli functioned as quotations marks with an explicitly negative load, to separate the words of the opponent from those of the author, and to emphatically reject the offensive statements. At the same time the obeli were warning signals to prevent readers from mistaking the heretical arguments of a Jovinian, Cassian, or Gottschalk for the opinions of the orthodox authors Jerome, Prosper, or Hincmar. To fulfil this threefold purpose - quotation, rejection, warning - the signs had to remain connected to the text. In a period when the florilegium was a popular genre, and text passages were frequently lifted from their context to be used else-

supervision between 865 and the bishop's death in 882. J. DevisSE, Hincmar: archeveque de Reims 845-882, 3 vols. (Genève, 1976), 1, p. 57, note 208.

13 This example is more fully discussed in VAN RENSWOUdE and STEINOVÁ, "The annotated Gottschalk".

${ }^{14}$ Hincmar of Reims, preface to De una et non trina deitate, PL 125, cols. 473c-476c: "ponens cum integritate sui in hoc opusculo nostrae servitutis ejusdem Gothescalci schedulas, et per singulas sententias more veterum obelum $\div$, id est jacentem virgulam eis opponemus, ut quasi sagitta falsa illius dicta confodiat" (Isidore of Seville, Etymologiae, I, 21, 3). On marking his own citations from the orthodox fathers with the sign of the chresimon, see Hincmar, De una, PL 125, col. 476c: "his vero quae opponentur ex orthodoxorum dictis ejus sententiis figuram $\mathbb{*}$, quae chresimon dicitur praenotabimus". 
where, this may have been a necessary safety precaution. Although one could argue that there is no question of censorship as long as nothing is suppressed or deleted, the practice of marking someone's words with a mark of rejection (in this case the ultimate rejection: heresy) does affect the author's status and hinders his chances of inclusion in the canon of approved authors and books.

We have little manuscript evidence of obeli that served as actual deletion signs. ${ }^{15}$ It could be argued that this is hardly surprising, since passages that were marked for removal would have disappeared anyway, obeli and all. It is a familiar aphorism that censorship hardly ever leaves a material trace, but in a manuscript culture removal usually does leave traces, in fact, in the form of visibly scratched surfaces with vaguely legible script, even when the spot was overwritten. Yet not every decision to scratch, delete, or skip a part of a text is necessarily an act of censure. It is in fact inherent in the culture of the handwritten book to 'customise' every copy of a text and tailor it to the needs of a specific community of readers, or to the preferences of an individual user. We only need to think of epitomes, florilegia and scholar's notebooks to see that point. We do however have descriptive texts from the early Middle Ages that prove that obeli were indeed used to mark words and passages for deletion. The bishops who issued the Acts of the Third council of Constantinople (680-681), for example, ordered to remove forged sections from the acts of a previous conciliar meeting from all extant codices. The bishops assumed that these sections were interpolations inserted by heretics, because they contained terminology that was offensive to the orthodox faith. Folia were to be removed from the codices in their entirety, and where this was not possible, the incriminated passages had to be marked with obeli, to indicate that they had to be cut away ("obelis obduci in locis, quibus depravati sunt, et caxari"). ${ }^{16}$

When did the sign of the obelus gain this role in the execution of censorship? In Antiquity, the obelus was used as a tool for textual criticism. In the ninth century, when Archbishop Hincmar employed the obelus to "pierce

15 MSS St. Gallen, SB 261 (mid-ninth century; St. Gallen); 670 (ninth century; St. Gallen); 257 (mid-ninth century; St. Gallen). See STEINOvÁ, Notam superponere studui, p. 283.

${ }^{16}$ It could be argued, however, that in spite of the violent verb caxari the obeli were not meant to cut anything away. Obelisation is here presented as an alternative to removal, precisely because removal was impossible in practice. But perhaps the verb caxari did imply an instruction to scratch the obelised passages from the parchment. Acta conciliorum oecumenicorum II, 2,1, ed. R. RIEDINGER (Berlin, 1990-1992), p. 647-649: “Chartacium quidem volumen, qui falsatum est, decernimus caxari in locis, in quibus adiectiones sunt factae, verum libros etiam eos OBEAIL$\Theta H N A I$ obelis obduci in locis, quibus depravati sunt, et caxari". 
through false arguments as an arrow", not for the purpose of text emendation but to reject the opinions of his opponent, he believed he was following ancient custom, and so did Isidore when he provided this definition in his sign list. To understand why and how the obelus gained this censuring function, we need to turn to the history of the symbol in Antiquity and its transformation in late Antiquity, when the sign was adopted by Christian scholars and polemicists.

\section{The Alexandrian Method}

The grammarian Zenodotus of Ephesus ( $f l$. third century BCE), librarian of the famous library of Alexandria in Egypt, is credited with inventing the obelus, or rather with finding a new purpose for it. ${ }^{17}$ The story goes that Zenodotus, in an attempt to clean up Homer's work and rid it of contaminations that had accumulated over the ages, decided to draw a simple straight line in the margin whenever he encountered a spurious verse. Thus Zenodotus became the first critical editor of Homer and, to borrow an apt phrase from Keith Houston, "invented the field of literary criticism quite literally at a stroke". ${ }^{18}$ Other signs soon followed. We are told that one of Zenodotus's successors, Aristarchus of Samothrace (c. 216-145 BCE), came up with additional symbols to complement and fine-tune the editorial task of Zenodotus's obelus, such as the asteriscus (the 'little star' *), the diple $(>)$ and the diple periestigmene (the 'dotted diple'). In the course of time, the asterisk became a steady partner of the obelus. It served as a companion sign as well as a counterweight to the obelus, assisting in the complicated task of text comparison for which Zenodotus's obelus was not fully equipped on its own. ${ }^{19}$ This basic set, attributed to Aristarchus, was further supplemented and grew into a group of critical signs that are today still known among classical scholars as the 'Aristarchan symbols'.

While the critical signs were initially used to edit Homer's work, and were designed to critically assess verses, not prose, they crossed over to the study of

17 This paragraph is based on Houston, Shady Characters, pp. 97-119. For a fuller account I refer to STEINOVÁ, Notam superponere studui, in particular chapter 1: "The use of technical signs in Antiquity", pp. 19-57.

${ }_{18}$ Houston, Shady Characters, p. 99.

19 The star-shaped asterisk was used to mark genuine verses that had accidentally become duplicated, the obelus served, as before, to indicate spurious and corrupted material, while the two signs in combination (asteriscus cum obelo) denoted lines that were authentic in themselves but happened to be in the wrong place. 
other classical authors such as Plato and Hippocrates. In the third century $\mathrm{CE}$ the signs were applied to Scripture - a cultural transfer that opened up the field of biblical criticism. The Christian scholar Origen (184/185-253/254 CE), who received his education in Alexandria and was familiar with the methods of the Alexandrian school, adopted the critical signs to create a carefully annotated recension of the Septuagint: the Greek translation of the Hebrew Old Testament dating to the second century BCE. Legend has it that seventy scholars set out independently from each other to translate the Hebrew text into Greek. When they reconvened, it transpired that their translations were identical, which was taken as proof that the Translation of the Seventy (Septuagint) was the result of divine inspiration. When in the third century CE, however, the textual scholar Origen compared the Septuagint to the Hebrew text and to several more recent Greek translations, he found discrepancies. To offer readers insight into the differences between the versions, Origen made use of a selection of symbols from the Aristarchan set. ${ }^{20} \mathrm{He}$ used the obelus to mark passages in the Septuagint that did not occur in the more recent Greek translations from Hebrew, the asterisk to mark verses that occurred in these translations but were missing in the Septuagint, and when the two signs appeared together, it meant that the ordering in the Septuagint differed from that of the other text versions. It is important to note that Origen did not aim to create a new authoritative recension, nor did he express judgment on 'right' or 'wrong' choices of translation. His system was designed to allow readers to understand the differences between various versions. ${ }^{21}$

Yet one could argue that Origen did express judgment, when he decided to use the sign of the obelus, the roasting spit, to indicate which passages could not be found in the Hebrew text. Origen himself considered his act of comparing and annotating an act of krisis, 'judgment'.22 Yet what he judged was not the quality of the Greek translation of the Septuagint as such, for he considered the inspired authority of the Septuagint beyond doubt. ${ }^{23}$ His annotated recen-

${ }^{20}$ L.D. ReYNOLDS and N.G. Wilson, Scribes and Scholars: A Guide to the Transmission of Greek and Latin Literature (Oxford, 1968, repr. 1991), p. 49. Origen may, however, have taken the signs from elsewhere, since the practice of annotation with these particular signs was not limited to the school of Alexandria, but was more wide-spread and diverse in Antiquity. STEINOVÁ, Notam superponere studui, p. 40.

${ }^{21}$ Houston, Shady Characters, p. 101 and Origen, Commentary on the Gospel according to Matthew 15.14, ed. in: $P G$, col. 1293.

${ }^{22}$ Origen, Commentary on the Gospel according to Matthew 15.14, ed. in: PG 13, col. 1293.

23 A. Grafton and M. Williams, Christianity and the Transformation of the Book: Origen, Eusebius and the Library of Caesarea (Cambridge, MA, 2008), p. 121. 
sion of the Septuagint was a scholarly tool to facilitate text comparison, but at the same time it was a polemical instrument to be used in public debates between Christians and Jews and served, in the words of Origen, "to coax the Jews, and persuade them to give us copies that are not tampered with, and free from forgery". ${ }^{24}$

We can therefore regard Origen's obelus as a sign of judgment, not only in a text-critical but also in a polemical sense. Yet his 'obelisation' of the Septuagint did not entail an instruction to scribes to leave anything out when copying his edition. Such a directive was no part of the agency of his 'roasting spit'. Just as Zenodotus's obelus, Origen's obelus marked, but did not obliterate material. ${ }^{25}$ Scribes were expected to copy the marked passages integrally, obeli and all. The problem was that scribes failed to do this, or copied the signs incorrectly. ${ }^{26}$ If Origen had not altered anything in his recension of the Septuagint, this would not have caused much confusion. But Origen did make changes: he supplemented the Septuagint with verses from, amongst others, the Greek translation of Theodotion, a Jewish translation from the Roman period that did not have the same canonical status as the Septuagint. ${ }^{27}$ Thus he introduced alien material into the 'original' of the canonical Septuagint. Although Origen duly noted his additions with the sign of the asterisk, he would later be harshly criticised for this editorial intervention. ${ }^{28}$ Origen's annotated recension of the Septuagint, intended as a scholarly tool, came to be used in many churches in the Greek-speaking part of the Christian world, but also in the

${ }^{24}$ Ibid. p. 121. Origen believed that the discrepancies between the versions used in Christian churches and those used by the Jews were the result of the Jews' deliberate corruption of Scripture. Origen, Letter to Scipio Africanus 4, ed. in: $P G$ 11, col. 56-60, trans. GRAFTON and WiLliams, Christianity and the Transformation of the Book, p. 125. As for discrepancies between different available Greek translations, Origen blamed 'rogues' and careless and lazy copyists.

25 "We obelized those passages which did not appear in the Hebrew, not daring to remove them entirely" (Origen, Commentary on the Gospel according to Matthew 15.14, ed. in: PG 13, col. 1293, trans. GRAFTON and Williams, Christianity and the Transformation of the Book, p. 125).

${ }^{26}$ J. DinES, "Textual developments to the fifth century CE", in: The Septuagint, ed. J. DiNES and M. KNIBBS (London, 2005), pp. 81-104.

27 Reynolds and Wilson, Scribes and Scholars, p. 49; Grafton and Williams, Christianity and the Transformation of the Book, p. 116.

${ }_{28}$ Origen's decision to add material would later be criticised by Jerome; see further on in this article. It is not certain if Origen ever intended his annotated and supplemented recension of Septuagint to circulate as a freestanding text, but it did. GRAFTON and WiLLIAMS, Christianity and the Transformation of the Book, p. 119. 
churches of the Latin West. ${ }^{29}$ Yet not all users were familiar either with the guiding principles of Origen's edition or with the meaning of the critical signs.

As far as we know, it was Origen who was the first Christian scholar and text critic to adopt the critical signs, but it was the priest Jerome of Stridon (c. $347-420 \mathrm{CE}$ ) who gave the editorial method currency among Christian readers, translators and texts critics in the Latin West. ${ }^{30}$ Jerome revised the Latin Bible in accordance with Origen's recension of the Septuagint and added Origen's critical signs to his revisions and translations, while giving the impression that it was his own invention. ${ }^{31} \mathrm{He}$ became known as an expert on this particular method of annotation and served as a 'helpdesk' for contemporaries who did not quite understand what these asterisks and obeli were doing in their copies. ${ }^{32}$ "The asterisk lets the light shine, while the obelus cuts and pierces", Jerome patiently explained on one of the many occasions he dealt with the topic. ${ }^{33}$ Yet

29 Jerome, Preface to the Commentary on the book of Daniel, ed. in: Hieronymus: Commentariorum in Danielem libri III, ed. F. GLORIE (Turnhout 1964: CCSL 75A), pp.774: "Cumque omnes Christi ecclesiae, tam Graecorum quam Latinorum Syrorumque et Aegyptiorum, hanc sub asteriscis et obelis editionem legant"; see also G.J.M. BARTELINK, Hieronymus, Liber de optimo genere interpretandi (epistula 57): Ein Kommentar (Leiden, 1980: Mnemosyne Supplements 61), p. 103.

${ }^{30}$ SteInOVÁ, Notam superponere studui, p.40; M. VeSSEY, "Jerome and Rufinus", in: The Cambridge History of Early Christian Literature, ed. F. Young, L. Ayres, and A. Louth (Cambridge 2010), pp. 318-27.

${ }^{31}$ Jerome consulted not only Origen's annotated Septuagint but his entire Hexapla when he revised the Latin books of the Old Testament (on the Hexapla, see supra, note 20). Megan Williams observed that Jerome never acknowledged using Origen's annotated recension when he made his translations of the Septuagint. He claimed that he compared the Hebrew and Greek texts himself, and added the asterisks and obeli on his own initiative. M.H. WILLIAMS, The Monk and the Book: Jerome and the Making of Christian Scholarship (Chicago and London, 2006), p. 80. Only later, when he turned his back on Origen's recension of the Septuagint and the critical signs, he would say explicitly that the method was Origen's (see further on in this article).

${ }^{32}$ See Jerome's letter to the Gothic priests Sunnia and Fretela (between 404-410), Ep. 106, 7, ed. in: Saint Jérôme, Lettres. Texte établi et traduit, ed. J. LABOURT, 8 vols. (Paris, 1955), vol.5, pp. 104-144, and also his letter to Augustine (c. 404), Ep. 112, 9, ed. in: CSEL 55, HILBERG, that will be discussed further on. For all other instances where Jerome explained the function of the asterisk and obelus, see STEINOVÁ, Notam superponere studui, pp. 301-303. Jerome's letter 106 is dated differently in each study. I am following the date given in J.N.D. Kelly, Jerome, his Life, Writings and Controversies (London 1975), p. 285.

${ }_{33}$ Jerome, Preface to the Pentateuch, ed. in: Biblia sacra: Iuxta Vulgatam versionem, ed. R. WeBER, 18 vols. (Stuttgart 1969) 1, p. 3: "asterisco et obelo, id est stella et veru, opus omne distinguens, dum aut inlucescere facit quae minus ante fuerant aut superflue quaeque iugulat et confodit". I have paraphrased Jerome's explanation. The full translation runs: "[Origen] equipped the entire work with asterisk and obelus, that is the star and the roasting spit, and thus he either made to shine what was lacking before, or slayed and pierced through what was superfluous". 
in the course of time Jerome became more critical of Origen's method, as will be explained below, and gradually voiced his criticism stronger in response to what has become known as the first Origenist controversy. ${ }^{34}$ It was this controversy that brought out a new function of the obelus as an instrument of censure.

\section{The Origenist Controversy}

In the late 390s, Jerome had a falling out with his friend Rufinus of Aquileia (c. 345-410) over the question of how to relate to the works of Origen now that his reputation became increasingly tinged with heresy. Was it permissible to translate the work of an acknowledged heterodox author and thus give his suspicious views an audience in the Latin West? Origen would be formally condemned only centuries later, at the Synod of Constantinople, but his theological views had been under fire for much longer. ${ }^{35}$ Initially, as mentioned, Jerome had been a great admirer of Origen, especially of his method of biblical exegesis, and he had translated many of Origen's biblical commentaries. Yet, when Epiphanius of Salamis (c. 310/320-403) started a fanatical campaign against followers of Origen in the $390 \mathrm{~s}$, Jerome soon joined his cause to protect his own reputation as an orthodox writer. ${ }^{36}$ His friend Rufinus, with whom he entertained a prolonged discussion about Origen's legacy, was not deterred by the anti-propaganda and issued in 397 a (rather free) translation of Origen's On First Principles, a work that contained precisely some of Origen's more controversial ideas on the Trinity, the resurrection of the body, and the status of the soul. ${ }^{37}$ One of the arguments Rufinus put forward in defence of Origen (and

Note how similar Isidore's description of the obelus (see supra, note 9) is to the wording of Jerome (who must have been his source), using the same verbs.

${ }^{34}$ On the background and development of the Origenist controversy, see E.A. CLARK, The Origenist Controversy: The Cultural Construction of an Early Christian Debate (Princeton, 1992).

${ }^{35}$ During the Christological controversies of the fourth century, Origen's theological views came to be regarded as 'proto-Arian.' There is still discussion among scholars over whether or not the condemnation of the Synod of Constantinople of 544 was ratified at the ecumenical council of Constantinople in 553.

${ }^{36}$ The same Epiphanius had just recently explained and defended Origen's method of annotating Scripture with asterisks and obeli in his treatise On measures and weights and numbers and other things that are in the divine scriptures (c. 392). Epiphanius of Salamis, De mensuris et ponderibus, c. 2, 3, ed. in: $P G$ 43, cols. 237-293.

37 On the formerly cordial relations between Jerome and Rufinus, see KELLY, Jerome, His Life, Writings and Controversies, p. 136, and VESSEY, "Jerome and Rufinus", p. 323. 
of his own choices as transmitter of Origen) was that the heretical ideas that could be found in Origen's work had been inserted by heretics. ${ }^{38}$ Origen was fully orthodox, Rufinus maintained, but his texts had been tampered with.

Rufinus was well aware that this argument would not be sufficient, and that he would face fierce criticism in the current contentious atmosphere, especially from Jerome. In his preface he tried to mitigate the criticism beforehand by pointing to the fact that Jerome himself had been a fervent admirer of Origen, and that his Latin translations had been instrumental in spreading knowledge of Origen's learning. He, Rufinus, would humbly follow Jerome's illustrious example and would offer a cleaned-up version of Origen's text, just as Jerome had done before him. Jerome was not amused. He had never been an indiscriminate consumer of Origen's work, he countered, but had always used his discretion when reading his books. True, he had admired Origen's biblical commentaries, but not his speculative work, such as the book Rufinus had now translated. ${ }^{39}$ What Rufinus had said about his method of translation, moreover, was pertinently untrue. ${ }^{40}$

Although the quarrel between Rufinus and Jerome was triggered by a specific cause, the contention over the reception of Origen's books, it soon branched out to the question of how to deal with heterodox texts in general. Should heretical and suspicious authors be avoided altogether and their works erased from memory, or was there a way to salvage what was good in heterodox texts without polluting the minds of innocent readers with heretical ideas? Would a simple obelus, a plain stroke in the margin, suffice to take away the risk of corrupting innocent minds? And who would be the one to assume the responsibility for such a project? Who could be trusted with the authority to distinguish between right and wrong, between what was orthodox and heterodox? The controversy was as much about methods of textual criticism and

${ }^{38}$ Rufinus, Preface to the Translation of Origen's On First Principles (Peri Archon) addressed to Macarius (c. 397/398), ed. in: Opera Tyrannius Rufinus, ed. M. SimONETTI (Turnhout, 1961: CCSL 20), pp. 245-246, at 246. It was an argument he had used before in his book On the Falsification of the Books of Origen (De adulteratione librorum Origenis) and elsewhere. Clark, The Origenist Controversy, p. 12, n. 18.

39 Jerome, Letter to Pammachius and Oceanus (c. 398/399), Ep. 84, written to defend himself against Rufinus' allegations. Ep. 84, 2, ed. in: Hieronymus epistolae, ed. I. HiLBERG (Vienna and Leipzig, 1910-1918: CSEL 55), pp. 121-134; Cf. Ep. 82, 7.

${ }^{40}$ For Jerome's defence against Rufinus, see his letter to Pammachius and Oceanus (c. 398/399), Ep. 84, ed. HiLBERG (CSEL 55) and Jerome's Apologia contra Rufinum (c. 402), ed. in: Saint Jérôme, Apologie contre Rufin, ed. and trans P. LARDET (Paris, 1983: SC 303). These texts will be further discussed below. 
transmission of knowledge as it was about authority and about the question of who was allowed to hold the 'censor's rod' (censoria virgula).

\section{How to Translate a Heretic}

Rufinus and Jerome took different stances on the problematic issue of how to transmit (or not) heterodox texts. Let us take a closer look at their arguments, which they exchanged via prologues, defences, and letters, sometimes directly aimed at each other, but more often via intermediary addressees. Not all the passages that I have selected for analysis deal directly with the obelus or other critical signs, but to be able to understand how the meaning and use of the obelus gradually shifted towards an instrument of censure, we need to look at it from a wider perspective and take their views on translation, textual criticism, and the reception of heterodox authors on board. Especially the issue that was frequently discussed in the fourth century and flared up again in the 390s of what makes a good translation, is highly relevant to the present topic, since the question at issue - is a translator at liberty to delete, alter, or add anything that he finds in the original text? - is intimately bound up with the notion of censorship. The fact that Jerome and Rufinus understood the enterprise of translating as an act of interpretation and judgment is significant in this respect. ${ }^{41}$

Rufinus's preface to his translation of Origen's On First Principles - the text that fuelled the quarrel with Jerome and spelled the end of their friendship - was written in 397 or 398 CE. The preface was addressed to Rufinus's friend Macarius who had commissioned the translation. As Rufinus tells Macarius, he initially hesitated to comply with his request, but then decided on a safe course of action: he would follow the example of Jerome and adopt his method of translation.

I have done so on this condition and on this understanding, that in making the translation I should follow as far as possible the method of my predecessors, and

${ }^{41}$ To denote the act of translating, Jerome and Rufinus not only employed the Latin verb transferre (transport, transpose, transfer), but more frequently the verb interpretari, the meaning of which ranged from 'interpreting' to 'explaining and translating'. It was closely connected to assessing (censere). C.T. LEWIS and C. SHORT, A Latin Dictionary (Oxford, 1879, repr. 1996), p. 884. Both Rufinus and Jerome regularly discussed exercising judgment (sententia, iudicium, arbitrium) as one of the main responsibilities of the translator-interpreter. 
especially of him of whom I have already made mention [Jerome]. He, after translating into Latin more than seventy of the books of Origen which he called Homiletics, and also a certain number of the Tomes, proceeded to purge and pare away (elimauit atque purgavit) in his translation all the causes of stumbling which are to be found in the Greek works; and this he did in such a way that the Latin reader will find nothing in them which jars with our faith. In his steps, therefore, I follow, not, indeed, with the power of eloquence which is his, but, as far as may be, in his rules and method, that is, taking care not to promulgate those things which are found in the books of Origen to be discrepant and contradictory to one another. ${ }^{42}$

According to Rufinus, Jerome had cleaned up the books of Origen by omitting the offensive parts in his translations. Rufinus states his intention to follow his example and leave out the parts that are "discrepant and contradictory to one another". As Rufinus will explain further on in the preface, such contradictions surely indicated that the Origenian corpus had been interpolated, and that spurious material had been inserted by heretics and false Christians for obvious malicious reasons. ${ }^{43}$ Although Rufinus, just like Jerome, was familiar with Origen's signs and methods of annotation, ${ }^{44}$ he did not adopt Origen's strategy to mark spurious passages with an obelus, but left them out altogether because they were contrary to the truth and to Origen's own teaching:

Wherever therefore I have found in his books anything contrary to the truth concerning the Trinity which he has in other places spoken of in a strictly orthodox sense, I have either omitted it as a foreign and not genuine expression or set it down in terms agreeing with the rule of faith which we find him constantly assenting to. There are things, no doubt, which he has developed in somewhat obscure

${ }^{42}$ Rufinus, Preface to On First Principles, ed. SimONetTi (CCSL 20), pp. 245-246: “... ea tamen lege atque eo ordine, ut quantum fieri potest in interpretando sequar regulam praecessorum et eius praecipue viri, cuius superius fecimus mentionem. Qui cum ultra septuaginta libellos Origenis [quos homileticos appelavit, aliquantos etiam de tomis in apostolum scriptis] transtullisset in Latinum, in quibus cum aliquanta offendicula inveniantur in Graeco, ita elimauit omnia interpretando atque purgavit, ut nihil in illis quod a fide nostra discrepet Latinus lector inveniat. Hunc ergo etiam nos, licet non eloquentia viribus, disciplinae tamen regulis in quantum possumus sequimur, observantes scilicet ne ea, quae in libris Origenis a se ipso discrepantia inveniuntur atque contraria, proferamus"; trans. W. H. FREMANTLE, Rufinus and Jerome (New York, 1892, repr. 2007: Nicene and Post-Nicene Fathers, Second Series 3), p. 428.

${ }^{43}$ Rufinus reveals here his philological method: if an idea, expression, or choice of words is not consistent with the rest of an author's work, then the material must be spurious.

${ }^{44}$ Rufinus, Defence against Jerome / Apologia contra Hieronymum II, 36 and 40, ed. SimONETTI (CCSL 20, pp. 111 and 114-115); GRAFTON and Williams, Christianity and the Transformation of the Book, p. 94. 
language, wishing to pass rapidly over them, and as addressing those who have experience and knowledge of such matters; in these cases I have made the passage plain by adding words which I had read in other books of his where the matter was more fully treated. I have done this in the interest of clearness: but I have put in nothing of my own; I have only given him back his own words, though taken from other passages. $^{45}$

When knowledge of Rufinus's translation spread and the text moved beyond the intimate circle of his friends for which he (as he claimed) had intended it, it excited a controversy in Rome. ${ }^{46}$ Readers wondered if such a far-reaching interference with a text did not amount to falsification. Was Rufinus restoring and improving the text, or was he corrupting it? ${ }^{47}$

The fact that Rufinus in his preface to the translation had pointed to Jerome's "method and rule" to justify his proceedings put Jerome in a precarious position. Just recently Jerome himself had been charged with accusations of falsification because he had taken too much liberty as a translator, according to his critics. ${ }^{48}$ Now Rufinus raked the issue up again, and Jerome once more felt the need to defend his reliability as translator-interpreter. What was perhaps even more embarrassing for Jerome, was that Rufinus put him down as an admirer of Origen, at a time when Jerome tried to distance himself from Origen's legacy.

Jerome's friends Pammachius and Oceanus urged him to clear himself from suspicions, as appears from a letter they sent Jerome in 398. They admon-

${ }^{45}$ Rufinus, Preface to On First Principles, ed. M. SimONETTI (CCSL 20), p. 246: "Sicubi ergo nos in libris eius aliquid contra id invenimus, quod ab ipso in ceteris locis pie de Trinitate fuerat definitum, velut adulteratum hoc et alienum aut praetermisimus aut secundum eam regulam protulimus, quam ab ipso frequenter invenimus adfirmatam. Si qua sane velut peritis iam et scientibus loquens, dum breviter transire vult, obscurius protulit, nos ut manifestior fierit locus, ea quae de ipsa re in aliis eius libris apertius legeramus adiecimus explanationi studentes. Nihil tamen nostrum diximus, sed licet in aliis locis dicta, sua tamen sibi reddimus"; trans. FREMANTLE, Rufinus and Jerome, p. 428

46 Williams, The Monk and the Book, p. 100.

47 Pammachius and Oceanus, Letter to Jerome (c. 398), published as Epistola 83 in the collection of Jerome's letters: Ep. 83, ed. HiLBERG (CSEL 55), pp. 119-120. For the date of the letter, see Kelly, Life, Writings and Controversies, p. 236.

${ }^{48}$ Jerome, Letter to Pammachius (395), Ep. 57, ed. BARTELINK, De optimo genere interpretandi, pp. 11-21. Although the problem with this particular translation may rather have been the fact that Jerome, assuming the text was for private use only, had added caustic comments in the margin, see Kelly, Life, Writings and Controversies, p. 203. As Jerome explained in his letter to Pammachius (Ep. 83), the translation was meant to be a private text; it was not intended for circulation. 
ished him to state publicly that Rufinus had lied..$^{49}$ The problem was, Rufinus had not lied. Jerome could hardly deny that he had indeed admired Origen and had translated many of his books, although, as he hastened to add, only his biblical commentaries, never his speculative theological work. Since he could not simply deny the charges, he decided that attack was the best defence ${ }^{50} \mathrm{In}$ his reply to Pammachius and Oceanus, he vehemently claimed the right to read heterodox authors. Who could forbid him to read the Institutes of Tertullian, or the excellent treatises of Apollinaris, just because they had erred on some points? ${ }^{51}$ Had the apostle Paul not said: "Test all things, hold fast to that which is good"? (1 Thess 5,21$)$. It would do him no harm to read Origen, Jerome said, or even to express his admiration for Origen's talent, precisely because he acknowledged his mistakes:

When once you have rejected these misstatements and have parted them with your censor's rod, so to speak, from the faith of the Church (quasi censoria virgula separaveritis a fide ecclesiae), I may read what is left with safety, and having first taken the antidote need no longer dread the poison. ${ }^{52}[\ldots]$ Will it be pretended, that I was bound to accuse a man [Origen] whose works I was translating by special request? That I was bound to say in my preface: "This writer whose books I translate is a heretic: beware of him, reader, read him not, flee from the viper: or, if you are bent on reading him, know that the treatises which I have translated have been garbled by heretics and wicked men; yet you need not fear, for I have corrected all the places which they have corrupted", that in other words I ought to have said: "the writer that I translate is a heretic, but I, his translator, am a Catholic". ${ }^{53}$

49 Pammachius and Oceanus, Letter to Jerome (c. 398), Ep. 83, ed. HILBERG (CSEL 55), pp. 119-120, at p. 120: "purga ergo suspiciones hominum et convince criminantem, ne, si dissimulaveris, consensisse videaris".

50 Jerome, Letter to Pammachius and Oceanus (398/399), Ep. 84, 4, ed. HILBERG (CSEL 55), pp. 121-134, at p. 127.

${ }_{51}$ ID., Ep. 84, 7, ed. HILBERG (CSEL 55), p. 128.

52 The meaning of this metaphor is rather cryptic in the context of this sentence, but can be better understood when compared with another letter in which Jerome used the same metaphor. In a letter to abbot Paul of Concordia (Jerome, Ep. 10), Jerome reassured the abbot that he (Jerome) could safely read a text of the schismatic Novatian without getting infected by its poison, if he would take a sip of the orthodox Cyprian by way of antidote. Whether one could read a heterodox text without getting 'poisoned', depended on one's skills of judgment and sound understanding of orthodoxy.

${ }_{53}$ Jerome, Ep. 84, 7, ed. HILBERG (CSEL 55), p. 129: “Cum haec rejeceritis, et quasi censoria virgula separaveritis a fide ecclesiae, tuto legam cetera nec venena iam metuam, cum antidotum praebibero. [...] Nisi forte accusare debui, cuius rogatus opuscula transferebam, et dicere in prologo 'hic cuius interpretor libros hereticus est, cave lector, ne legas. fuge viperam aut, si 
Jerome recognised Origen's mistakes for what they were, he countered, while Rufinus glossed them over as heretical insertions. Rufinus raised difficulties for his readers, Jerome continued, by asking them to "examine the whole life of the author and to form a judgment on the question from the remainder of his writings" ${ }^{54}$ At the same time he made it impossible for those same readers to form their own judgment precisely because he had removed the heretical passages from Origen's work. What made things even worse: Rufinus had not done a very thorough job and had left parts of Origen's text untouched that were, in Jerome's view, equally heretical, although perhaps less conspicuously so. This was harmful for readers, Jerome argued, because they were led to believe that Rufinus had purged the text for them and had rendered it safe to read. $^{55}$

Jerome accused Rufinus of acting like an "unjust censor" ("iniquus censor"), who expelled some members from the Senate, while keeping others in the curia. "Who gave you permission", Jerome demanded, "to cut out so many passages from the work you were translating?" ${ }^{97}$ Rufinus's editorial interventions indeed come close to what we would today label as censorship, except for the motivation that informed his interference with the text. Rufinus maintained he did not remove the heretical parts to avoid offending the sensitivities of Catholic readers, or protect them from infection with heresy, but in order to restore the text to what he considered to be its authentic form, and on top of that improve it in accordance with what he knew to be Origen's intentions. As Rufinus would explain later, when he was pressed to defend his method, he did not remove or alter anything because it was contrary to the

legere volueris, scito a malis hominibus et hereticis corrupta esse, quae transtuli. quamquam timere non debeas; ego enim omnia, quae fuerant vitiata, correxi. Hoc est aliis verbis dicere: 'ego, qui interpretor, catholicus sum; hic, quem interpretor, haereticus est'"; trans. FREMANTLE, Jerome: Letters and Select Works (Peabody, 1893, repr. 1995: Nicene and Post-Nicene Fathers, Second Series 6), p. 179.

${ }^{54}$ Jerome, Ep. 84, 7, ed. HiLBERG (CSEL 55), p. 131: “injecistis legentibus scrupulum, ut totam auctoris vitam discuterent, et ex caeteris libris eius conjecturam praesentis facerent questionis"; trans. FREMANTLE, Jerome: Letters and Select Works, p. 179.

55 ID. Ep 84, 7, and ID., Defence against Rufinus / Apologia contra Rufinum II, 11, ed. P. LARDET (SC 303), pp. 128-132.

56 Jerome, Defence against Rufinus / Apologia contra Rufinum, II, 11, ed. P. LARDET (SC 303), p. 130: "Aliud est si, iniquus censor eiusdem criminis, reos alius de senatu pellis, alios in curia retines". The reason why Rufinus is an unjust censor, according to Jerome, is because he is guilty of the same crime, i.e. heresy.

${ }^{57}$ Ibid. p. 128: "Quis tibi dedit hanc licentiam ut multa de interpretatione decideris?". 
Catholic faith, but only what was discrepant from Origen himself. ${ }^{58}$ Thus he underlined that his attitude towards the text was basically that of a text critic who aimed to reconstruct the original, uncorrupted form of the text, not that of the censor shielding readers from immoral or offensive content.

What Jerome's preferred method of dealing with heterodox texts is, however, does not become clear in this letter. With his fictional preface ("this writer whose books I translate is a heretic: beware of him, reader, read him not, flee from the viper" $)^{59}$ he ridicules Rufinus's strategy of alerting readers. Rufinus, to his mind, is more concerned with establishing a reputation for himself as an intelligent and most Catholic editor than with the interests of his audience. So what was a translator-interpreter, according to Jerome, supposed to do with heterodox authors and heterodox opinions? $?^{60}$

58 Rufinus, Defence against Jerome / Apologia contra Hieronymum I, 14, ed. SIMONETTI (CSEL 20), pp.37-143, at p. 47: "quem dixi, quia non proferam ea quae in libris Origenis a se ipso discrepantia inveniuntur atque contraria. Non enim generaliter promisi me non prolaturum quae essent fidei contraria, sed quae sibi ipsi essent contraria, vel quae a semetipso discreparent, non quae a me vel ab alio aliquo discreparent"; trans. FREMANTLE, Rufinus and Jerome, p. 441: "What I said was that 'I would not reproduce the things which are found in the books of Origen discrepant and contrary to his own true opinion'. I did not make a general promise that I would not reproduce what was contrary to the faith, nor yet what was contrary to me or to someone else, but what was contrary to or discrepant from Origen himself'.

59 We do find such warning notes added to heretical texts in early medieval manuscripts, where the notes are either scribbled in the margin of the text, or added on a slip of parchment, or on an empty folio preceding the text. See, e.g. a ninth-century manuscript of Prudentius On Predestination against John the Scot / De praedestinatione contra Ioannem Scottum, MS Paris, BNF, lat. 2445 , f. 1 bis (i.e. slip of parchment preceding f. 1r), where an annotator warned readers against the heterodox ideas expressed in the book: "Iste liber qui quasi ad defensionem fidei contra infidelitatem loquitur et testimonia scripturarum atque catholicorum nomina profert caute legendus est et in eius lectione apostoli est sequenda sententia qua dicit 'omnia probate, quod bonum est tenete' (1 Thess 5, 21). Nam compositor eius Prudentius de quibusdam ecclesiasticis dogmatibus non sensit catholice sicut alia eius scripta demonstrant". Just like Jerome, this annotator draws on the Apostle Paul's advice to "test all things, hold fast to that which is good" ("omnia probate, quod bonum est tenete").

${ }^{60}$ Initially I assumed that in this letter Jerome professed to a strategy of silent emendation without bothering the reader with the reasons for the editorial interventions. This I concluded from the line in Ep. 84, 7, ed. HILBERG (CSEL 55), p. 131: "Ego callidus, qui emendavi, silens quod volui, et dissimulans crimina, non feci invidiam criminoso"; trans. FREMANTLE, Jerome: Letters and Select Works, p. 179: "I on the other hand have been wise enough to emend silently what I wished to emend: thus by ignoring the crime I have averted prejudice from the criminal". But I rather think that Jerome is speaking here with the voice of Rufinus, as he did before in the same letter. Jerome would hardly say that he "averted prejudice from the criminal", i.e. Origen, if this is precisely what he accused Rufinus of. Nor would he describe his own way of dealing with heterodox texts as callidus ('sly', 'cunning'). Jerome did, however, emend Origen's texts 


\section{The Censor's Rod}

In his letter to Pammachius and Oceanus, Jerome mentioned the necessity of applying the censoria virgula, the 'censor's rod', to detect misstatements in the work of an author. Jerome's censoria virgula alludes to the virga, the 'rod' or 'whip' of a Roman magistrate that symbolised his power and jurisdiction. Just as a Roman censor exercised control over the moral conduct of citizens and had the power to expel a person from the Senate on grounds of immoral conduct, just so, is the implication, a Christian critic should separate misstatements from the faith of the Church. Scholars take Jerome's use of the expression censoria virgula as a reference to the critical sign of the obelus, and interpret this passage to mean that Jerome was in the habit of obelising heretical passages.$^{61}$ In the words of Mark Vessey, "what Jerome would do was 'dagger' or obelise, that is - following the practice of Hellenistic critics of Homer - to place an obelos or short horizontal stroke in the margin to the left of the spurious verse or passage". ${ }^{62}$ Vessey observed that Jerome used this phrase, censoria virgula, most often in connection with the theological 'editing' of Origen. ${ }^{63}$ By marking a passage in Origen's writing with the mark of the obelus he judged the passage spurious "with respect to an imagined textual corpus of orthodoxy". This is a persuasive interpretation, yet I dare propose another one. Although virgula is indeed a common Latin term to refer to the critical sign of the obelus, ${ }^{64}$ I doubt that Jerome uses it here to promote the obelisation of heretical texts. In fact, he had become wary of the critical marks of the asterisk and obelus. Instead I argue that Jerome's censoria virgula refers to the obelus

silently, as I will explain further on, but never admitted this to Rufinus. The crux of the matter, however, was above all addition (adding one's own words to a translation, or inserting material from another text), rather than deletion as such.

${ }^{61}$ D. Rohmann, Christianity, Book-Burning and Censorship in Late Antiquity (Berlin and Boston 2016: Studies in Text Transmission: Arbeiten zur Kirchengeschichte 135), p. 218, n. 88; M. VESSEY, 'The forging of orthodoxy in Latin Christian literature: A case study', Journal of Early Christian Studies 4.4 (1996), pp. 495-513, at p. 511; P. LARDET, L'Apologie de Jérôme contre Rufin: Un commentaire (Leiden, New York, and Boston, 1993: Supplements to Vigilae Christianae: Texts and Studies of Early Christian Life and Language 15), p. 63.

${ }^{62}$ VESSEY, 'The forging of orthodoxy', p. 511.

${ }^{63}$ Ibid.

${ }^{64}$ Quintilian in his Institutes of Oratory employed the same Latin expression (censoria virgula) in reference to the practice of annotating verses with the graphic symbol of the obelus; see further on in this article, and note 109. When talking about the critical sign of the obelus, Jerome used either the term obelus or denoted the sign with the Latin terms virga, transversa virga, veru, virgula, or iacens linea. BARTELINK, De optimo genere interpretandi, p. 103 
in a metaphorical sense. It is significant that he adds the word quasi to censoria virgula: "as if with a censor's rod". Jerome is not talking about a scribal practice but about a mental act of censure: a way of reading and interpreting heterodox texts. ${ }^{65}$ Before going into this matter further, Jerome's change of heart regarding the critical signs needs to be examined in more detail.

\section{Jerome Criticises the Critical Signs}

Already before 392, several years before the Origenist Controversy, Jerome had embarked on a project to translate all the books of the Old Testament directly from the Hebrew, without the intermediate stage of the Septuagint. In later centuries, Jerome's new Latin translation would become the normative translation known as the Vulgate, but initially his initiative was criticised, amongst others by Augustine, who failed to see why this was necessary. Augustine wrote to Jerome that, frankly, he preferred his earlier translations of books of the canonical Septuagint. He also wondered where the asterisks and obeli had gone in Jerome's new translation. ${ }^{66}$ Jerome responded in a huff that Augustine did not seem to understand the matter: ${ }^{67}$

Do you wish to be a true admirer and partisan of the Seventy translators? Then do not read what you find under the asterisks; rather erase them from the volumes, that you may approve yourself indeed a follower of the ancients. If, however, you do

${ }^{65}$ It should be noted that the passage just cited from Ep. 84 is the one instance where censoria virgula could indeed refer to an actual practice of obelisation, if it were not (amongst other reasons that will be explained further on) for the addition quasi. Compare to Isidore of Seville, Etymologiae, I, 21, 2-3 (cited supra, note 9), whose "quasi sagitta" is a metaphor, and "virgula" the name of the critical sign. Rufinus interpreted this particular passage in Jerome's letter as a reference to canon formation, not obelisation of heterodox texts, see infra, note 104.

${ }^{66}$ Jerome, Letter to Augustine (404), Ep. 112, 19, ed. HiLBERG (CSEL 55), p. 389: "Quod autem in aliis quaeris epistolis, cur prior mea in libris canonicis interpretatio asteriscos habeat et virgulas praenotatas et postea aliam translationem absque his signis ediderim"; trans. J.G. Cunningham, The Letters of St. Augustine (New York, 1886; repr. 2007: Nicene- and PostNicene Fathers, First Series 1), p. 341: "In another letter you ask why a former translation which I made of some of the canonical books was carefully marked with asterisks and obeli, whereas I afterwards published a translation without these". Jerome wrote his reply in 404, but this particular question from Augustine stemmed from a letter written much earlier.

${ }^{67}$ Ibid., ed. HILBERG(CSEL 55) p. 389: "pace tua dixerim-videris mihi non intelligere quod quaesisti"; trans. Cunningham, The Letters of St. Augustine, p. 341: "You must pardon my saying that you seem to me not to understand the matter". 
this, you will be compelled to find fault with all the libraries of the Churches; for you will scarcely find more than one manuscript here and there that does not have them. ${ }^{68}$

With the passing of years, Jerome grew increasingly disappointed with the quality of the Septuagint translation and dissatisfied with Origen's annotated recension. ${ }^{69} \mathrm{He}$ came to regard Origen's celebrated system of adding asterisks and obeli a form of text corruption, despite its meticulous precision. ${ }^{70}$ Ever since he began to recognise the flaw of the system, he acknowledged that this method of annotation was actually Origen's, and not his own. ${ }^{71}$ As he explained to Augustine, Origen was to blame for introducing alien material into the Septuagint, notably from the translation of Theodotion, "a Jew and a blasphemer". ${ }^{72} \mathrm{He}$ trusted that his own new translation, directly from the Hebrew, would be useful in polemics with Jews who ridiculed Christians for using the faulty Septuagint, quoting verses that could not be found in the Hebrew text. ${ }^{73}$ Scholars, such as Jerome himself, were able to rebut such attacks because they understood how and why the texts differed, but not every Christian user of the

${ }^{68}$ Jerome, Letter to Augustine (404), Ep.112, 19, ed. HiLBERg (CSEL 55), p. 389: “Vis amator esse verus septuaginta interpretum? Non legas ea, quae sub asteriscis sunt, immo rade de voluminibus, ut veterum te fautorem probes. Quod si feceris, omnes ecclesiarum bibliothecas condemnare cogeris. Vix enim aut alter invenietur liber, qui ista non habeat"; trans. CUNNINGHAM, The Letters of St. Augustine, p. 341.

${ }^{69}$ BARTELINK, De optime genere interpretandi p. 69. This is not to say that he never referred to the Septuagint in his commentaries again, but he gave precedence to the Hebrew text. WILLIAMS, The Monk and the Book, pp. 65, 120, 124.

70 Jerome, Letter to Augustine (404), Ep.112, 19, ed. HILBERG (CSEL 55), p. 389: "et miror, quomodo septuaginta interpretum libros legas non puros, ut ab eis editi sunt, sed ab origine emendatos sive corruptos per obelos at asteriscos".

${ }^{71}$ See supra, note 31.

72 Jerome, Letter to Augustine (404 CE), Ep.112, 19, ed. Hilberg (CSEL 55), p. 389: "praesertim cum ea, quae addita sunt, ex hominis iudaei atque blasphemi post passionem christi editione transtulerit". Jerome did not care to point out that he had himself transmitted these additions from Theodotion when he revised and translated books of the Latin Old Testament with the help of Origen's recension, without acknowledging these additions in his prefaces.

${ }^{73}$ Jerome's polemical purpose is very similar to the one Origen proposed to legitimise his annotated recension of the Septuagint, see Origen's Letter to Scipio Africanus 4, ed. in: $P G 11$, cols. 56-60. Jerome explained the reasons for making a new translation in the letter-preface to the first result that came out of this translation venture: the psalter according to the Hebrew text (392). Here, he is not yet negative about Origen's recension and its critical signs, but he points out that one type of translation is suitable for study, another for arguments with Jews, and another for regular use in churches. Jerome, Preface to the Psalter after the Hebrew Text, addressed to Sophronius, ed. WEBER, Biblia sacra, vol. 10, p. 6. 
Septuagint had that knowledge. ${ }^{74}$ Many people, Jerome discovered, did not understand that the critical signs indicated textual variants; not even Augustine fully grasped the meaning of the asterisks and obeli. Some readers even mistook the obeli that Jerome had added to his earlier translations for deletion marks, and accused Jerome of 'truncating' the books of Scripture. ${ }^{75}$ Jerome appears to have reached the conclusion that the asterisks and obeli were helpful as a tool of interpretation and textual criticism for scholars, but unsuitable for a wider audience of users. ${ }^{76}$

What Jerome did consider a very useful textual practice, especially for less educated readers, was punctuation per cola et commata. ${ }^{77}$ By adding spaces between words and breaking the text up in sense units - a technique he had

${ }^{74}$ See the preceding note. The letter-preface is addressed to Sophronius, who was apparently very confused about the variety of different translations, and had recently been outmanoeuvred in a discussion with a Jew, precisely because he did not understand the textual differences between the Septuagint, other Greek translations and the Hebrew text.

75 Jerome, Preface to the Commentary on the book of Daniel (407), ed. GloRIE, Hieronymus: Commentariorum in Danielem libri III, p.774: "Unde et nos ante annos plurimos cum verteremus danielem, has visiones obelo praenotavimus, significantes eas in hebraico non

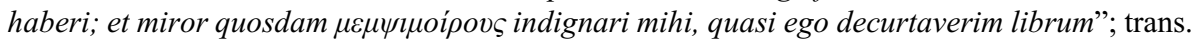
G.L. ARCHER, Jerome's Commentary on Daniel (Eugene, 1958; repr. 2009), p. 17: "For this same reason when I was translating Daniel many years ago, I noted these visions with an obelus, showing they were not included in the Hebrew. And in this connection I am surprised to be told that certain fault-finders complain that I have on my own initiative truncated (decurtare) the book". Here, visiones does not refer to the dreams of Daniel, but to the stories of Susanna, Bel, and the Dragon and the three young men, as Jerome explained in the same preface. See also infra, note 98 .

${ }^{76}$ Jerome, Commentary on Ezechiel (417), vII, 23, ed. Hieronymus, Commentarium in Hiezecheliem libri XIV, ed. F. GLORIE (Turnhout, 1964: CCSL 75), p. 317; ID., Preface to the Psalter after the Hebrew text (392) ed. WEBER, Biblia sacra, vol. 10, p. 6 (see supra, note 73), and see ID., Ep. 106, 46 (between 404-410), ed. LABOuRT, Saint Jérôme, pp. 124-126, where he argues that the annotated Psalter (after Origen's recension) fitted the needs of the erudite in their study of Scripture, while the old (not-annotated, unrevised) Septuagint Psalter was better suited for singing in the churches: "Hoc enim quod Septuaginta transtulerunt, propter vetustatem in ecclesiis decantandum est; et illud ab eruditis sciendum propter notitiam Scripturarum".

${ }^{77}$ In the sixth century, Cassiodorus (see further on in this article) believed that Jerome's innovation to mark his translations by cola and commata was led by consideration for the simple brothers, who had not learned punctuation from the teachers in the schools of secular learning. Cassiodorus may well have been right, but Jerome does not say this explicitly. Cassiodorus, Institutions of Divine and Secular Learning I, preface, 9, ed. Cassiodori senatoris institutiones, ed. R.A.B. MyNORS (Oxford, 1937; repr. 1963), p. 8: "Illud quoque credimus commonendum, sanctum Hieronymum simplicium fratrum consideratione pellectum in Prophetarum praefatione dixisse, propter eos qui distinctiones non didicerant apud magistros saecularium litterarum colis et commatibus translationem suam, sicut hodie legitur, distinxisse". 
encountered in copies of the speeches of orators - he trusted his translations would be easier to understand and better fitted to read aloud. ${ }^{78}$ Jerome furthermore adopted the practice of adding comments, explanations, or alternative versions in the margins of his translations, which he wrote out in full (possibly as an alternative to annotation with asterisks and obeli), but discovered to his dismay that not all readers and scribes understood that textual convention either. ${ }^{79}$ In his letters and prefaces to biblical commentaries and translations, we can see Jerome experimenting with different techniques, introducing "new ways of distinction", to make texts accessible to a differentiated audience of Christian readers and text users. ${ }^{80}$ Some of these adaptations and innovations were successful, others, he found, were not.

It is not known what Augustine thought of Jerome's change of mind regarding the critical signs. ${ }^{81}$ Rufinus, however, found Jerome's shifting position rather taxing. Reminding Jerome of his regular references to Origen's signs, he exclaimed in exasperation: "How is this? You produce Origen sometimes for condemnation, sometimes for imitation, at your own caprice!" 82 Jerome in his

78 See Jerome's preface to his translation of Ezechiel, ed. WEBER, Biblia sacra, vol.15, p. 6, and the preface to his translation of Isaiah, ed. WeBER, Biblia sacra, vol.13, p. 3. Malcolm Parkes lists Jerome's technique of dividing the text per cola et commata among the "aids for inexperienced readers". M.B. PARKeS, Pause and Effect: An Introduction to the History of Punctuation in the West (Aldershot, 1992), pp. 15, 16.

${ }^{79}$ In his letter to the Gothic priests Sunnia and Fretela (between 404-410), Ep. 106, ed. LABOURT, Saint Jérôme, Lettres, pp. 124-125, Jerome expressed his shock upon discovering that the comments he added in the margin of the Psalter to explain the text to readers, had been copied into the main text and were taken to be part of Scripture itself: "Et miror quomodo e latere adnotationem nostram nescio quis temerarius scribendam in corpore putaverit, quam nos pro eruditione legentis scripsimus hoc modo", which is followed by the admonition to prevent scribes from making this mistake again: "Unde si quid pro studio e latere additum est, non debet poni in corpore, ne priorem translationem pro scribentium voluntate conturbet". Both citations make clear that Jerome considered his marginal annotations as study aids.

80 Jerome's preface to his translation of Isaiah, ed. WEBER, Biblia sacra, vol.13, p.3: "novo scribendi genere distinximus".

${ }^{81}$ In his own work, Augustine continued mentioning the signs used in Origen's edition project without any criticism, although he did point out that annotation with asterisks and obeli was useful but limited, in the sense that these critical signs did not meet all possible requirements of text comparison. See Augustine, The City of God / De civitate Dei (begun after 410 and completed in the 420s), XVIII, 43, ed. Augustinus, De civitate Dei libri XI-XXII, ed. B. DomBART, A. KALB (Turnhout, 1955: CCSL 48), p. 639. Here, Augustine respectfully acknowledges Jerome's Latin translation from the Hebrew text, indicating that Jews consider Jerome's translation a more faithful rendition than the Septuagint. Augustine nonetheless promotes the 'Old Latin' translation from the Septuagint to be used in Latin churches.

${ }^{82}$ Rufinus, moreover, had a different interpretation of what Origen's asterisks and obeli 
turn accused Rufinus of being a "latter-day Aristarchus" because he was "so ready to express judgment on all writers". ${ }^{83}$ These accusations to and fro show that to Jerome and his contemporaries, the text-critical tradition of Aristarchus and the Hellenistic grammarians was intricately connected to acts of judgment (sententia) - both on the quality of the text at hand and on the status of authors.

\section{Editorial Intervention}

In his letter to Augustine of 404, Jerome defended his principles of translation and argued that it was important to stay close to the text at hand, especially if it concerned Scripture. Sometimes a paraphrase or a change of the order of words was needed to make the text comprehensible. On certain occasions it was even permissible to simplify an argument for the sake of uneducated readers, ${ }^{84}$ but changing the essential meaning of a text via additions and alterations was to be considered unacceptable. ${ }^{85}$ Yet if it was indeed Jerome's ideology as

judged: not the Septuagint, but the Hebrew text (cherished by Jerome) was corrupted. Rufinus, Defense against Jerome / Apologia contra Hieronymum II, 40, ed. SIMONETTI (CCSL 20), p.114. The full quotation runs: "Sed et Origenes - inquit - asteriscos fecit, ex translatione Theodotionis adsumens, ut conponeret volumina quae appelantur Hexapla. Et quid? Origenem istum, quando tibi non placet, condemnandum; quando placet, imitandum producis? Verisimile est ut eundem tu et defensorem adhibeas et reum?"; trans. FremantLe, Rufinus and Jerome, p. 476-7: "But Origen also, you will tell us, in composing his work called the Hexapla, adopted the asterisks, taking them from the translation of Theodotion. How is this? You produce Origen sometimes for condemnation, sometimes for imitation, at your own caprice. But can it be admitted as right that you should bring in the same man as your advocate whom just now you were accusing?". For Rufinus' alternative interpretation of the judgment that Origen expressed with his asterisks and obeli, see further on in the same chapter of his Defense against Jerome (II, 40). Here, he compared the obelus to the theta, the sign of death employed in military lists. Just as a general, Rufinus said, adds the sign of the theta to the name of a deceased soldier not to condemn him to death, but simply to state a fact, so the obelus does not delete or curtail anything, but only states a fact: this material is spurious / false / corrupted.

83 Jerome, Ep. 57, 12, ed. BARTELINK, De optimo genere interpretandi, p. 20: “Quid ais, o columen litterarum et nostrorum temporum Aristarche, qui de universis scriptoribus sententiam feras?". Here Jerome attacks Rufinus under the assumption that Rufinus was the main critic behind the campaign against Jerome's free translation of the letter of Epiphanius.

${ }^{84}$ See Jerome's defence for making a simplified translation for a monk in his monastery, who had explicitly asked him to do so. Jerome, however, hastened to add that this translation was intended for private use, not for public circulation. Jerome. Ep. 57, 2, ed. BARTELINK, De optime genere interpretandi, p. 11

85 Jerome, Ep. 57, 5, and see the interpretation of BARTELINK, De optime genere interpretandi, p. 6. My summary of Jerome's exposé on the best method of translation, which he first set 
a translator to remain close to the text and not interfere with its form and content beyond what was necessary to produce an intelligible translation, then why had he altered Origen's texts? At least, that is what Rufinus said he did. Jerome surely differentiated between editing and translating Scripture and transmitting non-canonical texts, but what level of textual interference did he deem acceptable for a translator-interpreter of heterodox texts? What should be left to the judgment of the reader, and what to the judgment of the editor?

To address this issue, we need to return to the argument between Jerome and Rufinus over the best method of editing and translating the writings of heterodox authors. Especially the defences (apologiae) they directed at each other in the final stage of their quarrel, between 400 and 402, are revealing in this respect. After Rufinus had issued his free translation of Origen's On First Principles that created, in the eyes of his critics, the false impression that the author had been fully orthodox, Jerome retaliated by making a very literal translation of Origen's text. Thus he distanced himself from Rufinus's claim that he was following Jerome's method, by demonstrating that his own principles of translating were wholly different. In the accompanying letter-preface to Pammachius and Oceanus, Jerome explained that if it had not been for Rufinus's truncated and misleading version, he would never have translated such a speculative text of Origen as the On First Principles, filled with theological errors. $^{86}$

In the meantime Jerome wrote a separate letter to Rufinus to patch things up. The bottom line of the letter was: I understand why you did what you did, but I implore you not to let this get out of hand and turn into a public controversy. Others, Jerome said, would not be as understanding as he was. ${ }^{87}$ Rufinus, however, never received Jerome's letter of reconciliation. He did read the

out in 395 in De optime genere interpretandi and repeated summarily in his letter to Augustine in 404, does not do full justice to the diversity and richness of his ideas. Following Cicero, Jerome aimed to translate as an orator, not as a mere translator. (Jerome, Ep. 57, 5: quoting Cicero: "nec converti ut interpres, sed ut orator"). To Jerome, translating a text "as an orator" meant respecting not only the content but also the form of a text. A translation should do justice to stylistic figures and render sense for sense, rather than word for word. This was a longstanding literary tradition of translating, Jerome argued, exemplified by Cicero, Horace, Terence, and Plautus, and followed by respectable Catholic translators such as Hilary of Poitiers and Evagrius. The title of the tract he issued in 395, De optime genere interpretandi was a reference to Cicero's De optime genere oratorum.

${ }^{86}$ See also Jerome, Letter to Pammachius and Oceanus, Ep. 84, 7, ed. Hilberg (CSEL 55), p. 131 .

87 Jerome, Letter to Rufinus, Ep. 81, ed. HILBERG (CSEL 55), pp. 106-107. 
letter-preface to Pammachius and Oceanus in which Jerome denied all charges, and he was furious. Yes, he had removed, altered, and changed passages that were contrary to Origen's thought, but could Jerome really insist with a straight face that he had never changed anything in his own translations of Origen? In his Defence against Jerome (Apologia contra Hieronymum, 400 CE), Rufinus emphasised over and over again that his method corresponded to Jerome's own method: "what did I do in this which was different or contrary to his system? what which was not identical with it?" Jerome had written earlier on the topic, and what he, Rufinus, had argued himself, he introduced a system of quotation signs which he had seen in Greek manuscripts. ${ }^{89}$ A single mark indicated a quotation from his own work, a double mark a passage from the work of his opponent. Thus he aimed to ensure that readers would not mistake the words of his accuser for his own, and prevent critics from misrepresenting his arguments. ${ }^{90}$ In his Defence against Je-

${ }_{88}$ Rufinus, Defense against Jerome / Apologia contra Hieronymum II, 50, ed. SiMONETTI (CCSL 20), p.122: "Dixi eum purgasse in Latina translatione si qua illa offendicula fidei videbantur in Graeco, et non immerito: ita tamen ut eadem etiam a me conprobem gesta. Nam sicut ille in omeliis de Esaia duo Seraphin Filium et Spiritum Sanctum esse interpretatus est, et addens de suo: 'Nemo aestimet in Trinitate naturae esse differentiam, cum nominum discernuntur officia', per hoc curare se credit offendicula potuisse, ita nos, vel ademptis vel immutatis quibusdam vel additis, sensum auctoris adducere conati sumus ad intelligentiae tramitem rectiorem. Quid hic diversum aut quid contrarium aut quid non idem fecimus?"; trans. FREMANTLE, Rufinus and Jerome, p. 481: "I said that when grounds of offence appeared in the Greek he had cleared them away in his Latin translation; and not wrongly; but he had done this just in the same sense as I have done it. For instance, in the Homilies on Isaiah, he explains the two Seraphim as meaning the Son and the Holy Ghost, and he adds this of his own: 'Let no one think that there is a difference of nature in the Trinity when the offices of the Persons are distinguished'; and by this he thinks that he has been able to remedy the grounds of offence. I in a similar way occasionally removed, altered or added a few words, in the attempt to draw the meaning of the writer into better accordance with the straight path of the faith. What did I do in this which was different or contrary to his system? what which was not identical with it?".

${ }^{89}$ C. HAMMOND BAMMEL, "A product of a fifth-century scriptorium preserving conventions used by Rufinus of Aquileia: I. Rufinus and western monastic libraries and scriptoria", Journal of Theological Studies, N.S. 29.2 (1978), pp. 366-391, at p. 381.

90 Rufinus, Defense against Jerome / Apologia contra Hieronymum I, 12, ed. SimONETTI (CCSL 20), p. 45: “... ut nihil careat teste quod dicimus. Sane ne in legendo error sit ex his, quae huic scripturae nunc aliunde inserimus, si quidem mea sunt, simplices ad uersuum capita habent notas; si accusatoris mei, duplices"; trans. FremANTLE, Rufinus and Jerome, p. 440: “... so that proof may be at hand for each statement. And further, to prevent the reader from falling into any mistake as to the passages which I insert from other documents, I have, where the quotation is from my own works, placed a single mark against the passage, but, where the words are those of my opponent (rather: accuser (accusatorem)) a double mark". Janneke Raaijmakers, who discusses this passage in her contribution to the present volume, observes: "Apparently, in this 
rome, Rufinus engaged in careful text comparison to prove that Jerome had deleted and altered passages from Origen before, and had added words of his own, by comparing the original Greek text of Origen's Homilies on Isaiah with Jerome's Latin translation. ${ }^{91}$ As Alfons Fürst argued, Jerome never acknowledged his authorship of the translation of these homilies of Origen precisely for this reason: it would have compromised him and put Rufinus in the right. For in his translation of the Homilies on Isaiah, Jerome had indeed altered Origen's text, added some orthodox explanations, and rendered the highly disputed text orthodox according to fourth-century standards. ${ }^{91}$ And Rufinus was able to prove it.

\section{Cleaning up Origen}

Rufinus could have saved himself the trouble of this carefully executed text comparison, had he known of a letter Jerome had written earlier. In another quarrel over the transmission of Origen's work, this time with the priest Vigilantius, Jerome said explicitly that he had cut away and altered parts of Origen's texts. ${ }^{92}$ In a vehement response to Vigilantius's criticism of his [Je-rome's] lingering admiration for Origen, Jerome reserved the right to read and translate Origen, precisely because he was able to recognise what was true and

turbulent period of polemic and intellectual challenges, in which every word was carefully weighed, scholars like Rufinus sought ways to mark their own viewpoints in the lay-out of the text and make visible their judgment of the texts of others".

${ }^{91}$ See supra, note 88 .

91 A. FüRST, "Jerome keeping silent: Origen and his Exegesis of Isaiah", in: Jerome of Stridon: His Life, Writings and Legacy, ed. A. CAIN and J. LöSSL (Farnhamn, 2009), pp. 141-152. I only partly agree with Fürst's explanation, because Jerome did acknowledge that he translated Origen's commentary on Isaiah and, what is more, that he had altered the text to make it more orthodox in his letter to Pammachius and Oceanus, Ep. 84, 3, ed. HiLberg (CCSL 55), pp. 123, 124: "in lectione Esaiae, in qua duo seraphin clamantia describuntur, illo interpretante filium et spiritum sanctum nonne ego detestandam expositionem in duo testamenta mutavi? habetur liber in manibus ante viginti annos editus"; trans. FREMANTLE, Jerome: Letters and Select Works, p. 177: "In the portion of Isaiah which describes the crying of the two seraphim, he (Origen) explains these to be the Son and the Holy Ghost; but have not I altered this hateful explanation into a reference to the two testaments? I have the book in my hand as it was published twenty years ago".

92 I am grateful to Janneke Raaijmakers for alerting me to this letter to Vigilantius, which she discusses in her contribution to this volume. Jerome uses the same arguments in his letter to Tranquillinus written in the same year (397) (Ep. 62), and see also his letter to Theofilus (Ep. 82). 
false. The readers, to whom he transmitted Origen's work, benefitted from his power of discernment, because they could "receive the good in his writing without anything of the bad":

Origen is a heretic, true; but what does that take from me who do not deny that on very many points he is heretical? [...] If I did not allow that he has erred or if I did not daily anathematise his errors I should be partaker of his fault. For while we receive what is good in his writings we must on no account bind ourselves to accept also what is evil. Still in many passages he has interpreted the Scriptures well, has explained obscure places in the prophets, and has brought to light very great mysteries, both in the Old and in the New Testament. If then I have taken over what is good in him and have either cut away or altered or ignored what is evil, am I to be regarded as guilty on the score that through my agency those who read Latin receive the good in his writings without anything of the bad? $?^{93}$

Here, in his letter to Vigilantius, Jerome prides himself on having protected readers against harm, and justifies his decision to interfere with the text by pointing to illustrious Catholic translators who went before him, such as Hilary of Poitiers and Eusebius of Vercelli, who exhibited a similar attitude towards transmitting the work of heterodox authors as he did, "omitting the unsound portions and rendering only those parts which are profitable". 94

Rufinus was probably not familiar with this letter to Vigilantius, otherwise he would have had ready ammunition to counter Jerome. The way Rufinus had edited Origen's text had indeed been Jerome's own method, with this difference that Rufinus explained his method to his readers, while Jerome silently deleted and altered parts of the text. ${ }^{95}$ Should we therefore regard Jerome's

93 Jerome, Letter to Vigilantius (397), Ep. 61, 2, ed. HILBERG (CSEL 54), p. 577: “Origenes haereticus: quid a me, qui illum in plerisque hereticum non nego? [...] si erasse non dicerem eum, et haec non cottidie anathematizarem, essem erroris illius socius. neque enim ita debemus bona eius recipere, ut mala quoque suscipere cogamur. at idem et scripturas in multis bene interpretatus est et prophetarum obscura disseruit et tam novi quam veteris Testamenti revelavit maxima sacramenta. si igitur, quae bona sunt, transtuli et mala vel amputavi vel correxi vel tacui, arguendus sum cur per me Latini bona eius habeant, ignorant mala?"; trans. FREMANTLE, Jerome: Letters and Select Works, pp. 131-132.

${ }^{94}$ Ibid. 61, 2, ed. HILBERG (CSEL 54), p. 577: “... licet heretica praetermittens optima quaeque transtulerit". Compare: Jerome, Letter to Theofilus, Ep. 82, 7; see the following note.

${ }_{95}$ See also Jerome, Letter to Theofilus (c. 399), Ep. 82, 7, ed. HILBERG (CSEL 55), p. 113: "Origenem me arguit vertisse in Latinum. Hoc non solus ego feci, sed et Confessor Hilarius fecit: et tamen uterque nostrum noxia quaeque detruncans, utilia transtulit"; trans. Fremantle, Jerome: Letters and Select Works, p. 173: "He charges me with having translated Origen into Latin. In this I do not stand alone for the confessor Hilary has done the same, and we are both at 
editing of Origen as an act of 'obelisation', as Mark Vessey suggested? Yes and no. For all we know, Jerome did not add obeli to the offensive parts in his translation, but left these parts out without a word. He may have put horizontal marks in the margin of his Greek exemplar to indicate which parts he wanted to leave out of his translation, but we have no evidence for this. ${ }^{96}$ It is equally possible that he mentally 'obelised' the heretical sections of Origen's text, judging in his mind which parts to take over and which parts to leave out, while making his translation. ${ }^{97}$

one in this that while we have rendered all that is useful, we have cut away all that was harmful".

${ }_{96} \mathrm{He}$ could also have used other excerption or deletion marks, but there is no way of telling without manuscript evidence.

${ }^{97}$ I found one instance where Jerome employed the obelus in the sense suggested by Vessey, i.e. to mark text as "spurious to an imagined textual corpus of orthodoxy" (VESSEY, "The forging of orthodoxy", p. 511).This instance is, however, not related to editing Origen or any other heterodox author, but to Scripture and canon formation. In the preface to his translation of the book of Daniel (c. 393), Jerome wrote that he marked the stories of Susanna, Bel, and the Dragon, and the three young men (that were recorded in the Septuagint but did not occur in the Hebrew text) with a veru (Latin for 'roasting spit') to indicate that these stories were to be considered subordinate to the canon of Scripture. Thus Jerome designated these passages as apocryphal (i.e. extra-canonical), distinguishing them from the canon, but without 'cutting them off' (detruncare). We see here again an explicit contrast between actual deletion and marking passages with an obelus (here: veru, although some manuscripts have obele or ebelo). According to Jerome, 'cutting off' (detruncare) was an act only the unskilled (inperiti) would engage in. Jerome, Preface to the Book of Daniel, ed. R. WeBER, Biblia sacra, vol. 16, p. 7: "Haec idcirco, ut difficultatem vobis Danihelis ostenderem, qui apud Hebraeos nec Susannae habet historiam nec hymnum trium puerorum nec Belis draconisque fabulas, quas nos, quia in tote orbe dispersae sunt, veru ante posito easque iugulante subiecimus, ne videremur apud inperitos magnam partem voluminis detruncasse". It is important to note that this preface dates to the period before the Origenist controversy, before Jerome abandoned the critical signs. See the critical apparatus on page 7 for manuscripts with the variant ebelo or obele. Readers, however, did interpret Jerome's obelisation of these passages in the Book of Daniel as mutilation or deletion, see his letter-preface to his commentary on Daniel in 407, cited supra, note 75 , where he looked back on annotating the Book of Daniel with the sign of the obelus, and the misunderstanding it caused among readers at the time. In the letter-preface of 407 he calls the sign he used back then obelus. 


\section{Censoria Virgula}

Jerome's letter to Vigilantius, in which he proudly explained his purging of Origen, was written before Rufinus made his translation and adaptation of Origen's On First Principles. After the controversy broke out, and especially after 400, when Rufinus's careful analysis of one of Jerome's translations demonstrated that Jerome deleted parts of Origen's text and added words of his own, Jerome never mentioned in any other letters that he was a silent emendator of Origen. ${ }^{98}$ Now that Rufinus had made the issue public, Jerome claimed a wholly opposite opinion on the responsibilities of the translator, which he voiced stronger as the quarrel proceeded. ${ }^{99}$ In his Defence against Rufinus (402), Jerome maintained that readers should not be kept in the dark but should be presented with the whole truth to be able to make their own decisions. It is the reader who should be the judge, according to Jerome, between the views of the two translators-interpreters after having been fully informed about the content of the heterodox text:

You [Rufinus] altered for the better the passages which you considered to have been put in by the heretics. I brought to light what the whole Greek world with one voice attributes to him. Which of our two views is the truer it is not for me nor for you to judge; let each of them feel the censor's rod (censoria virgula) of the reader. ${ }^{100}$

Thus Jerome made the issue of transmitting heterodox knowledge even more public than Rufinus had done: he turned it into a shared responsibility of translators and readers. The community of readers, which he had treated so far as a group that needed to be protected against heresy, should now be allowed to form its own judgment.

98 As he did in his letter to Vigilantius (Ep. 61, 397), his letter to Tranquillinus (Ep. 62, 397) and his letter to Theofilus (Ep. 82, 399); see supra, note 96.

${ }_{99}$ See, e.g. Jerome's challenging question to Rufinus in his Apologia of 404, cited earlier (see supra, note 56): "Who gave you permission to cut out so many passages from the work you were translating?", implying that he, Jerome, never did any such thing.

${ }^{100}$ Jerome, Defence against Rufinus / Apologia contra Rufinum, I, 11, ed. P. LARDET (SC 303), p. 34: "Tu enim emendasti quae addita ab haereticis arbitratus es; ego prodidi quod ab illo scriptum Graecia universa conclamat. Quis rectius arbitratus sit, nec meum nec tuum iudicium est. Utriusque scripta censoriam lectoris virgulam sentient"; trans. FREMANTLE, Rufinus and Jerome, p.489 
In this passage, Jerome uses the phrase censoria virgula again. Yet it is clear that he does not literally refer to the editorial practice of obelising texts, that is marking spurious passages with the sign of the obelus: he is talking about the virgula of the reader (censoriam lectoris virgulam), not that of the text critic. Although he takes the expression censoria virgula from the vocabulary of textual criticism, with an ironic allusion to the whip or rod of the Roman magistrate and the moral control of the censor, ${ }^{101}$ he speaks here of the power of judgment in a metaphorical sense, referring to the capacity of readers to judge for themselves what is true and what is false, who is right and who is wrong. On several occasions, Jerome emphatically claimed a licence to read Origen and other heterodox authors, and reserved the right to decide for himself what was heretical. He denied others the exclusive right to apply the "censor's rod'. No one should determine for him what he was allowed to read, to admire, or to translate, as long as he knew what he was doing. As he exclaimed to the priest Vigilantius, who had accused him of following Origen:

Is it for you alone, with that very wise head of yours, to pass sentence upon all writers Greek and Latin, with your censor's rod to eject some from our libraries and to admit others, and as the whim takes you to pronounce me either a Catholic or a heretic? ${ }^{102}$

It was not up to Vigilantius to judge him or to make decisions for him, Jerome maintained. He was very well capable of doing that himself, thank you very much. Rufinus in turn wondered who had handed Jerome his "censor's rod" with which he separated certain authors and teachers from the body of the Church and relegated them to a consortium of heretics. ${ }^{103}$ He used Jerome's

${ }^{101}$ Quintilian, Institutes of Oratory (Institutio oratoria) I, 4; see infra, note 109. Pierre Lardet considers Jerome's censoria virgula to be a reference both to the critical mark of the corrector and the rod that was the distinctive attribute of the Roman censor. LARDET, L'Apologie de Jérome, p.63: "alors que Jerome songe plutôt à la baguette, insigne de la fonction discriminatoire du censeur".

${ }^{102}$ Jerome, Letter to Vigilantius (397), Ep. 61, 2, ed. HILBERG (CSEL 54), p. 578: "Tibi soli

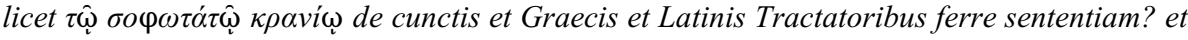
quasi censoria virgula, alios eiicere de bibliothecis, alios recipere: et cum tibi placuerit, me vel Catholicum vel Haereticum pronuntiare".

${ }^{103}$ Rufinus, Defense against Jerome / Apologia contra Hieronymum II, 26, ed. SIMONETTI (CCSL 20), p. 85: “... et inter haereticorum consortia tua censoria, tu ais, virgula segregas: quam virgulam a quo accipens nescio". Apparently Rufinus interpreted Jerome's allusion to an act of separation (segregare) with a censoria virgula in Ep. 84 (see supra, note 65) as a reference to canon formation, not to an obelisation of heterodox texts. 
own phrase ("tua censoria, ut ais, virgula"), including his allusion to the Roman censor to expel persons from the Senate, or degrade them to a lower rank. Was it Jerome's right, then, Rufinus asked, to make that decision? Was it up to him to determine who else was allowed to do so? "I know that Christ once gave the keys to Peter", Rufinus snapped, "but what kind of spirit nowadays hands out these censor's rods, is apparently for you to say". ${ }^{104}$

Both in Jerome's letter to Vigilantius and in Rufinus's Defence against Jerome, we see that the censoria virgula is used in the sense of judgment, of distinguishing right from wrong and, in this case, deciding which books and authors were to be admitted to the Catholic canon of reading, and which ones were to be excluded. This was not necessarily an act of textual criticism, or a textual activity at all, for that matter. On another occasion when Jerome denied an opponent the exclusive right to apply the censoria virgula, this was directed at a person who had criticised him orally "at street corners and in apothecaries' shops". ${ }^{105}$ That particular critic had never written anything against him, but only spoken out against him, which goes to show that the act of applying the censoria virgula, the censor's rod, was not limited to writing. It was essentially a mental act of censure that could be applied to reading, writing, speaking, and thinking about heterodox knowledge and the canon of acceptable learning.

\section{Precedents}

In his metaphorical use of the phrase censoria virgula, Jerome connected the sign of the obelus, the virgula or horizontal line of textual criticism, to censorship and canon formation. Although it would appear that the obelus gained this aspect in Christian scholarship during the patristic period in response to a conflict over interpretation and translation, we can detect earlier signs pointing in that same direction. As we have seen, Origen's method of annotation was an act of judgment (krisis) with a specific polemical purpose. Also in a non-Christian context we see a similar movement in the agency of the critical signs from textual to doctrinal criticism, from form to content. Origen's contemporary, Diogenes Laertius (third century CE) described in his Lives of

${ }^{104}$ Ibid.: "Nam Petrum semel scimus claves a Christo accepisse, istas modo censorias virgulas qui [quis] spiritus erogat, tu videris".

${ }^{105}$ Jerome, Letter to Domnio (394), Ep. 50, 4 ed. HILBERG (CSEL 54), p. 393: "garrire per angulos et medicorum tabernas". 
Eminent Philosophers how the Aristarchan critical signs were used to assess consistency with Plato's doctrine. ${ }^{106}$ Earlier, already in the first century BCE, the rhetorician Quintilian pointed to an association between the practice of obelising passages and censure. The textual criticism of the Alexandrian scholars, according to Quintilian, did not stop at marking passages as spurious, but also affected canon formation:

The old grammarians [that is the Alexandrian scholars] indeed carried their criticism so far that they were not content with just annotating verses with a censor's rod (censoria virgula) or rejecting books whose titles they regarded as spurious, ${ }_{107}$ as though they were expelling a suppositious child from the family circle, but also drew up a canon of authors from which some were omitted altogether. ${ }^{108}$

In that sense, when Jerome and his circle broadened the use and interpretation of critical signs to acts of judgment and canon formation, they did nothing new as such, but took the tradition of textual criticism a step further in a direction in which it was already heading. It would appear that it was Quintilian from whom Jerome borrowed the expression censoria virgula - a complex image that compared the agency of the graphic symbol of the obelus to an instrument

${ }^{106}$ Diogenes Laertius, Lives of the Eminent Philosophers, 3, ed. and trans. R.D. HICKS, 2 vols. (London, 1959-1965: The Loeb Classical Library), 1, pp. 334-35, cited in STEINOVÁ, Notam superponui studui, pp. 319, 320. From Diogenes Laertius' description it appears that the asterisk and obelus were used to mark what was spurious and what was authentic in texts of Plato not only in relation to form, but also with respect to content: "And since certain critical marks are affixed to his [Plato's] works, let us now say a word about these. [...] the dotted obelus [denotes] passages suspected without reason [...] the asterisk an agreement of doctrine, the obelus a spurious passage".

${ }^{107}$ In Christian canon formation similar principles of rejection were applied to those Quintilian's 'old grammarians' had used. According to the Decretum Gelasianum (s. VI CE), anonymous martyr acts could not be fully accepted by the church, because the name of the authors were unknown (and therefore the texts lacked authority): "gesta sanctorum martyrum [...] secundum antiquam consuetudinem singulari cautela in sancta Romana ecclesia non leguntur, quia et eorum qui conscripsere nomina penitus ignorantur" (Decretum Gelasianum de libris recipiendis et non recipiendis, ed. E. von DoBschüTz, Das Decretum Gelasianum de libris recipiendis et non recipiendis in kritischen Text herausgegeben und untersucht (Leipzig, 1912: Texte und Untersuchungen der altchristliche Literatur 38.4), p. 9).

${ }^{108}$ Quintilian, Institutes of Oratory / Institutio oratoria, , , 4, ed. and trans. H.E. BUTLER, The Institutio oratoria of Quintilian, 4 vols. (London, New York, 1921: The Loeb Classical Library), 1, p. 62: "Quo quidem ita severe sunt usi veteri grammatici, ut non versus modo censoria quadam virgula notare et libros, qui falso viderentur inscripti, tanquam subditos summovere familia permiserint sibi, sed auctores alios in ordinem redegerint, alios omnino exemerint numero". 
of physical punishment, the rod of the censor, as well as to discussions of inclusion and exclusion, inherent in canon formation.

\section{Following Jerome in the Early Middle Ages}

The obelus lived on as a tool of textual criticism and censure long after Jerome started to have his doubts about the suitability of the critical signs. Jerome's old annotated Psalter (which he in vain attempted to replace) even inspired a revival of the critical signs in the ninth century. ${ }^{109}$ Since Jerome initially let his readers believe that annotation with asterisks and obeli was his own initiative, his name stayed connected to the practice throughout the early Middle Ages. When, in the sixth century CE, the former senator Cassiodorus, now abbot of the monastery of Vivarium, instructed his monks on how to relate to heterodox texts from the past, he followed Jerome's example.

St. Jerome [...] convincingly showed how Origen is to be read. He would not prevent learned men from reading indispensable portions of his work, nor yet hurl the unwary to ruin. Some have properly said that Origen ought to be treated like anise; for though he seasons the food of sacred literature, he himself is to be cooked and when the flavour is extracted, thrown away. [...] So we must read him cautiously and judiciously to draw the healthful juices from him while avoiding the poisons of his perverted faith that are dangerous to our way of life. ${ }^{110}$

Cassiodorus had several methods of 'editing' or 'curating' heretical texts to make them suitable for reading. ${ }^{111}$ Which method he selected depended on the abilities of his intended audience. Advanced readers, who were trained in the art of interpretation, could be trusted with an undigested heretical text, while

${ }^{109}$ STEINOVÁ, Notam superponere studui, pp. 42, 120-126.

${ }^{110}$ Cassiodorus, Institutions of Divine and Secular Learning I, 1, 8, ed. MYNORS, p. 14: "sed quemammodum legi debeat [...] Hieronymus probabiliter indicavit, ut nec studiosos ab eius necessaria lectione removeat, nec iterum incautos praecipitet ad ruinam. quem quidam non immerito more anethi habendum esse dixerunt, qui dum sacrarum condiat pulmentaria litterarum, ipse tamen decoctus exsucatusque proicitur. [...] et ideo caute sapienterque legendus est, ut sic inde sucos saluberrimos assumamus, ne pariter eius venena perfidiae vitae nostrae contraria sorbeamus."; trans. J.W. HALPORN, introd. M. VESSEY, Cassiodorus, Institutions of Divine and Secular Learning, On the Soul (Liverpool, 2004: Translated Texts for Historians 42), p. 114.

${ }^{111}$ On Cassiodorus as a curator of heterodox texts, see also the contributions of Jesse Keskiaho and Luciana Cuppo in the present volume. 
it was better, Cassiodorus thought, to offer a purged version to beginners. Other readers could practice their skills of interpretation by reading a text that was marked with signs of rejection:

And so, as much as I could find in my cursory readings of Origen, I marked the passages that contained statements against the rules of the fathers with the sign of rejection, the achresimon. With such a mark on his perverted opinions indicating where he is dangerous, he cannot succeed in deceiving. ${ }^{12}$

Evina Steinová has convincingly argued that when Cassiodorus talked about the achresimon, the sign of rejection, he meant the obelus. ${ }^{113}$ Interestingly, Cassiodorus implied that by marking the books of Origen with the sign of rejection, he was doing exactly what Jerome had done. ${ }^{114}$ Yet we have no evidence, as I hope to have demonstrated in this article, that Jerome employed the obelus for this purpose. ${ }^{115} \mathrm{We}$ only know for certain that he used the obelus and its companion, the asterisk, as instruments of text comparison in his earlier translations and revisions of the books of the Old Testament, a practice he later abandoned. When it came to editorial interventions to heterodox texts, he seems to have preferred to emend a text silently for a wider audience of readers. ${ }^{116}$

${ }^{112}$ Cassiodorus, Institutions of Divine and Secular Learning, I, 1, 8, ed. MYNORS, pp. 14, 15 : "quapropter in operibus eiusdem Origenis, quantum transiens invenire praevalui, loca quae contra regulas Patrum dicta sunt achresimi repudiatione signavi, ut decipere non praevaleat qui tali signo in pravis sensibus cavendus esse monstratur"; trans. HALPORN, p. 114.

${ }^{113}$ See the analysis of Evina Steinová in VAN RENSwOUdE and STEINOVÁ, "The annotated Gottschalk".

${ }^{114}$ When Cassiodorus explained his methods of curating texts for different audiences, he explicitly referred to Jerome's letter to Tranquillinus (Ep. 62) - one of the many letters in which Jerome explained how he dealt with Origen. Nowhere in this letter, however, nor in any of his other letters on the subject, does Jerome say that one should mark Origen's books with signs of rejection. Rather, he talks about exercising judgment conform the advice of the apostle Paul "Prove all things and hold fast that which is good": one should select what is good and avoid what is bad in the writings of the heretics. Jerome, Letter to Tranquillinus (397), Ep. 62, ed. HILBERG (CSEL 54), pp. 583-584.

${ }^{115}$ With the exception of the example discussed supra, in note 98 . Yet there Jerome obelised passages as 'extra-canonical', not as heretical.

${ }^{116}$ According to John Kelly, Jerome did on occasion add caustic remarks in the margin, whenever he felt the urge to express disapproval (Kelly, Life, Writings and Controversies, p. 203). I assume that he did the latter especially for his learned colleagues, friends and above all: his critics and enemies, those who were able to understand the 'rules of the game' of textual, literary and doctrinal criticism. 
The considerations that led Cassiodorus to distinguish between different audiences of readers and text users, and to tailor his edition strategies to the needs and capacities of each different group, were similar to those that had previously guided the decisions of Jerome and Rufinus. Yet they never phrased it as explicitly and clearly as Cassiodorus did. In the late fourth century, when Christianity was pervading different levels of society, scholars such as Jerome and Rufinus needed to come to terms with a new reality of a varied audience of readers and text users. Christianity, being a book religion, required skills of interpretation and judgment that used to be the exclusive domain of the educated elite. Jerome and Rufinus each participated in the development of tools and strategies for making texts available to different readers and users, for private study or public reading. The margin of manuscript codices offered a plethora of possibilities to adapt and accommodate texts for specific groups of readers. In the late fourth century such possibilities were still being explored by trial and error. As far as Jerome was concerned, the introduction of asterisks and obeli to a wider audience should be considered an error. By the sixth century, when Cassiodorus wrote his recommendations on how to deal with heterodox texts, a differentiated readership had become an established fact of life, although in Cassiodorus's days, that reality was rapidly falling apart.

Memory of Jerome's (real or imagined) methods of critically assessing heterodox texts lived on after the disintegration and transformation of the world of classical learning, as becomes apparent from the last example that I discuss in this article. In the early eighth century, an unknown editor who called himself Jerome published a work entitled the Cosmographia. He said he had come across some old quires that contained this work, written by a certain philosopher from Istria named Aethicus, and decided to publish it. The attribution of the work was a fiction (no philosopher by the name of Aethicus Ister ever existed), and so was the identity the editor adopted for himself: he presented himself not as just any Jerome but as 'the' Jerome, church father and editor par excellence. This Ps.-Jerome recounted how he had annotated the original quires of Aethicus Ister's Cosmographia with cancellation marks (caraxaturas) $^{117}$ and obeli (virgulae) to indicate what he wanted to leave out of

\footnotetext{
${ }^{117}$ Michael Herren, whose edition and translation I here follow, explains in his commentary to the text that the word caraxaturas should not be understood as 'writings' as in Merovingian usage, but according to Insular usage as 'cancellation marks'. M.W. HerRen, The Cosmographia of Aethicus Ister: Edition, Translation and Commentary (Brepols, 2011: Publications of the Journal of Medieval Latin 8), p. 240.
} 
his epitome. ${ }^{118}$ His markings served a double purpose: the obeli he added to the pages of Aethicus's books assisted him in his editorial task, but also warned readers who would in future come across the original quires against the errors of ancient philosophy "by containing them [the errors] with a little lock (parvam repaculam retenendam)". ${ }^{119}$ Pseudo-Jerome's careful and precise account of how he annotated his pagan exemplar must have served to add credibility to his pretence to be the fourth-century church father Jerome. ${ }^{120}$ Regardless of the fictional setting, the story shows how much Jerome's name had become attached to the practice of annotating and censuring texts with the help of signs, and how it even became a mark of Jerome's identity as an editor and ultimate judge of heterodox texts.

${ }^{118}$ Cosmographia of Aethicus Ister, §66a, ed. HERREN, pp. 142, 143: “nonnulla quaedam peregrina et incredibilia in multis assertionibus [...], quae nobis nimis laboriosa curiositate cursim ad duo puncta posuimus caraxaturas et uirgulas" (“... some of their strange and incredible doings in numerous statements, which we by degrees and with very painstaking caution affixed with cancellation marks and obeli up to the two points"). My translation of duo puncta differs from the translation of Herren, who interprets them as two modes of punctuation. I think, however, that this is a reference to the metobelus that Jerome called duo puncta, literally: two points, which were added in the margin to indicate where the obelised passage ended, as Jerome explained in his preface to the psalter: "wherever he [the reader] sees the former [a horizontal stroke or obelus], he is to understand that between this mark and the two stops (duo puncta) which I have introduced, the Septuagint translation contains superfluous matter" ("Notet sibi unusquisque vel iacentem lineam [...] vel obelos [...] et ubicumque virgula praecedentem, ab ea vel usque duo puncta quae impressimus sciat in septuaginta translatoribus plus haberi").

${ }^{119}$ I have not encountered the image of the "little lock" ("parvam repaculam") to describe the function of the obelus elsewhere. Cosmographia §66a, ed. Herren, pp. 142, 143: "Itaque non tantum mea \{\} causa fuit eorum palpare et enucleare paginas, ut in aliquod rei veritatis proderer, quam a praecedentibus lectoribus errorem enigmatum illorum in palam obmissam, vel parvam repaculam retenendam, scidolas quaerellarum illorum futurumque lectorum scriptorumque panderem" ("And so it was not so much for my own sake that I touched up and summarised \{their\} pages with the intent of producing something factually true as it was to publish the folios of the investigations of those \{philosophers\} for future readers and writers by omitting the errors of those riddles that were in full view to previous readers, or by containing them with a little lock").

${ }^{120}$ M.W. HERREN, “The Cosmographia of Aethicus Ister: One more Latin novel?”, in: Fictional Traces: Receptions of the Ancient Novel, ed. M.H. PINHEIRO and S.J. HARRISON, 2 vols. (Groningen, 2011: Ancient Narrative Supplement 14), 1, pp. 33-54, at. p. 35. 


\section{Epilogue}

In the sixth century, and perhaps already earlier, the authority of Jerome became the measuring rod of canon formation. ${ }^{121}$ With hindsight, it would seem unavoidable that it was Jerome who was credited with the authority to hold the 'censor's rod', but at the time, as Andrew Cain has pointed out, Jerome was a marginal figure in the Origenist controversy. His ecclesiastical status was precarious, and he depended on his patrons to fund his scholarly work. ${ }^{122}$ By the time of the sixth century, his authority counted as normative in all matters of orthodoxy and heterodoxy. Jerome's judgment of authors and their books helped readers to decide whether they could read a heterodox text or not. Especially when it came to reading Origen, Jerome was the authority to go by. The sixth-century Decretum Gelasianum, ${ }^{123}$ the first list of banned books, ascribed to the fifth-century pope Gelasius, let the ultimate decision on Origen's books depend on Jerome's opinion. If Jerome had approved of a certain work of Origen, one could safely read it, if not, that book should be considered banned. ${ }^{124}$ Rufinus, on the other hand, suffered the consequences of quarrelling with Jerome: his writings ended up on the Decretum's list of books that could not be accepted without distinction. According to the Decretum, Rufinus was "a most religious man", but his ecclesiastical writings and translations could nonetheless not be fully approved, because "the venerable Jerome observed a (too) free judgment in some of his works" - a clear reference to Rufinus' liberal translation policies. ${ }^{125}$ Ironically, the Decretum Gelasianum let

${ }^{121}$ On Jerome's influence on establishing and maintaining categories of canonical and apocryphal reading in the Middle Ages, see E. Rose, Ritual Memory: The Apocryphal Acts and Liturgical Commemoration in the Early Medieval West (c. 500-1215) (Leiden, 2009: Mittellateinische Studien und Texte 40), pp. 49-62, esp. pp. 52, 53.

${ }^{122}$ A. CAIn, The Letters of Jerome: Asceticism, Biblical Exegesis and the Construction of Christian Authority in Late Antiquity (Oxford, 2009: Oxford Early Christian Studies) p. 33.

${ }^{123}$ Usually the Decretum is dated to the sixth or late fifth century. Rosamond McKitterick, however, argued for a date around 700 (R. MCKITTERICK, The Carolingians and the Written Word (Cambridge, 1989), pp. 202-204).

${ }^{124}$ Decretum Gelasianum de libris recipiendis et non recipiendis, ed. Von DoBschüTZ, p. 10: "Item Origenis nonnulla opuscula, quae vir beatissimus Hieronimus non repudiat, legenda suscipimus, reliqua autem cum auctore suo dicimus renuenda".

${ }^{125}$ Ibid., p. 10: "Item Rufinus vir religiosissimus plurimos ecclesiastici operis edidit libros, nonnullas etiam scripturas interpretatus est; sed quoniam venerabilis Hieronimus eum in aliquibus de arbitrii libertate notavit [...]". In some early medieval manuscripts of Rufinus' Historia ecclesiastica this verdict is repeated as a warning to readers; see, e.g., MSs Reims, Bibliothèque Carnegie (formerly the BM), 1351 (s. X) and 1352 (s. XI). 
the final verdict on the books of Rufinus depend on the judgment of his former friend Jerome:

we consider those [acceptable] which we know the aforementioned blessed Jerome considered [acceptable]; and not only those of Rufinus, but also [the books] of anyone whom that man, who is often remembered for his fervour for God and reverence for the faith, criticised. ${ }^{126}$

Thus the quarrel between the two former friends over the reception of heterodox knowledge and the best way to regulate it for a varied audience of Christian readers had far-reaching consequences for canon formation, as well as for their own position in the canon of acceptable and unacceptable knowledge. ${ }^{127}$

\section{Conclusion}

To return to the question with which I started this article: can the graphic symbol of the obelus be regarded as a sign of censorship? If we go by the traditional definition that I mentioned in the introduction, that is 'blocking something from being read, heard, or seen', then the obelus sometimes performed this function, at other times not. There are many examples of early medieval manuscripts where the obeli stayed in, together with the passages they marked, because they served a different purpose, ranging from denigrating one's opponent in a debate to offering aids of interpretation to readers, as highlighted in the first part of this article. In those cases, nothing was blocked from readers; they were even meant to see it. However, if we go by the classical meaning of censura, 'expressing judgment or opinion', this would be an apt description of the agency of the obelus in all instances. In every example that we have seen,

${ }^{126}$ Ibid., p. 10: “[...] illa sentimus quae predictum beatum Hieronimum sentire cognoscimus; et non solum de Rufino, sed etiam de universis quos vir saepius memoratus zelo dei et fidei religione reprehendit".

${ }^{127}$ It should be mentioned here that Rufinus did get a positive review in Gennadius' continuation of Jerome's catalogue of famous authors - a catalogue that was also highly influential with respect to canon formation during the Middle Ages. Jerome-Gennadius, De viris illustribus, ed. E.C. RICHARDSON, Hieronymus, Liber de viris inlustribus: Gennadius de viris inlustribus (Leipzig, 1896: Texte und Untersuchungen zur Geschichte der altchristlichen Literatur 14, 1a). On the contribution of De viris illustribus to the construction of "the Christian past in terms of books and authors", see R. MCKITTERICK, History and Memory in the Carolingian World (Cambridge, 2004), pp. 223-226, esp. 226. 
the obelus essentially expressed judgment, whether it was employed to 'pierce' a text as if with a roasting spit, lance or arrow, to flog an offensive statement as if with a censor's rod, or to 'contain' a text as if behind a lock, whether it assessed form or content, symbolically or practically. This act of judgment could lead to actual deletion, or to a mental act of distinguishing right from wrong. In the end, the obelus was exactly what Isidore of Seville said it was: a sign of judgment. 
